\title{
Paleohydrological dynamics in the Western Mediterranean during the last glacial cycle
}

\author{
Antonio García-Alix ${ }^{a, b, *}$, Jon Camuera ${ }^{c}$, María José Ramos-Román ${ }^{c}$, Jaime L. Toney ${ }^{\mathrm{d}}$, \\ Dirk Sachse $^{\mathrm{e}}$, Enno Schefuß ${ }^{\mathrm{f}}$, Gonzalo Jiménez-Moreno ${ }^{\mathrm{a}}$, Francisco J. Jiménez-Espejo ${ }^{\mathrm{b}, \mathrm{g}}$, \\ Alejandro López-Avilés $^{\mathrm{a}}$, R. Scott Anderson ${ }^{\mathrm{h}}$, Yurena Yanes ${ }^{\mathrm{i}}$ \\ ${ }^{a}$ Department of Stratigraphy and Paleontology, University of Granada, Granada, Spain \\ ${ }^{\mathrm{b}}$ Instituto Andaluz de Ciencias de la Tierra (IACT), CISC-UGR, Armilla, Spain \\ ${ }^{\mathrm{c}}$ Department of Geosciencies and Geography, Faculty of Science, University of Helsinki, Finland \\ ${ }^{\mathrm{d}}$ School of Geographical and Earth Sciences, University of Glasgow, UK

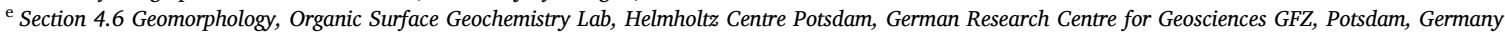 \\ ${ }^{\mathrm{f}}$ MARUM-Center for Marine Environmental Sciences, University of Bremen, Bremen, Germany \\ ${ }^{g}$ Biogeochemistry Research Center, Japan Agency for Marine-Earth Science and Technology, Yokosuka, Japan \\ ${ }^{\mathrm{h}}$ School of Earth and Sustainability, Northern Arizona University, Flagstaff, AZ, USA \\ i Department of Geology, University of Cincinnati, USA
}

\section{A R T I C L E I N F O}

Editor: Dr. Fabienne Marret-Davies

\section{Keywords:}

Southern Iberian Peninsula

Leaf waxes

Hydrogen isotopes

Paleohydrology

Mid-low latitude rainfall systems

Last glacial-interglacial transition

Holocene

Western Mediterranean precipitation

West African monsoon

\begin{abstract}
A B S T R A C T
The transitional regions between the low and high latitudes of the Northern Hemisphere are highly vulnerable to future climate change yet most of the current climate models usually diverge in their projections. To better understand the dynamics in these regions, the reconstruction of past hydrological fluctuations and precipitation patterns is of paramount importance to accurately constrain present and future climate scenarios. In this study, we investigated paleohydrological dynamics in the western Mediterranean region, a transitional zone between low-mid latitudes and Atlantic - Mediterranean realms. We reconstruct precipitation and moisture source changes during the last $\sim 35 \mathrm{ka}$ in order to propose the potential mechanisms driving these oscillations. To do so, we use hydrogen isotopes from sedimentary leaf waxes, more specifically the $C_{31} n$-alkane homologue, and a precipitation proxy based on previously published pollen data from a sedimentary core (Padul-15-05) in southern Iberia (Padul wetland $\sim 37^{\circ} \mathrm{N}$ ). With this combination we disentangle the coupled effect of precipitation amount and source on the hydrogen isotopic signature of the studied $\mathrm{C}_{31} n$-alkane record. Our results show three main periods characterized by different precipitation patterns. Low precipitation, mainly linked to a significant contribution from an isotopically-enriched Mediterranean precipitation source, occurred from $\sim 30$ to $\sim 15.5 \mathrm{ka}$ $\mathrm{BP}$ and during the last $\sim 5 \mathrm{ka}$, whereas enhanced precipitation with a predominant isotopically-depleted Atlantic precipitation source prevailed from $\sim 15.5$ to $\sim 5 \mathrm{ka}$ BP. This latter stage is here defined as the Western Mediterranean Humid Period (WMHP). In addition, some occasional millennial-scale opposite precipitation patterns can be observed during these climatically distinct periods. These changes in the source of precipitation were likely coupled to a shift in the main rainy season from winter, when Atlantic precipitation prevailed, to late winter-early spring, when the contribution of Mediterranean moisture is higher. Comparison between the studied mid-latitude terrestrial Padul-15-05 core and a low-latitude marine record offshore of northwestern Africa shows clear long-term synchronous responses of both western Mediterranean precipitation and western African monsoon systems to northern Hemisphere atmospheric dynamics, ultimately controlled by orbital forcing and ice-sheets fluctuations.
\end{abstract}

\footnotetext{
* Corresponding author at: Department of Stratigraphy and Paleontology, University of Granada, Granada, Spain.

E-mail address: agalix@ugr.es (A. García-Alix).
} 


\section{Introduction}

The climatic and environmental features of the Mediterranean region, such as high summer temperatures and summer drought, make this area particularly vulnerable to global climate change (Giorgi, 2006). Thus, extremely adverse future environmental scenarios are expected for this region, showing among others, warmer summers and precipitation decreases, and thus, an increase in summer drought and desertification (IPCC, 2014; Dong et al., 2021). Furthermore, the impact of climate change on the Mediterranean region differs from the expected behavior in this latitudinal belt since changes in the atmospheric moisture budget do not totally follow global temperature fluctuations (D'Agostino and Lionello, 2020). These climate model discrepancies are especially evident when they are tested using long-term proxy-based paleohydrological reconstructions (IPCC, 2013). This complexity is likely to be related to the location of the Mediterranean region between tropical and mid-latitude climate belts, a transitional realm with strong climatic contrasts at both temporal and spatial scales resulting from diverse atmospheric patterns acting synchronically with different intensity and effects (Lionello et al., 2006; Trigo et al., 2006). The Mediterranean area represents the northernmost influence of the north African tropical Hadley Cell regime (low-level flow in the ascending branch) that controls the African summer monsoon (Raicich et al., 2003), and the southern limit of the north Atlantic storm tracks that have a great impact on Mediterranean winter precipitation (Trigo et al. 2006). In addition, the Mediterranean Sea is an important global source of moisture and heat reservoir (Lionello et al., 2006; Volosciuk et al. 2016). Consequently, precipitation in the western Mediterranean area is not only affected by frontal depressions from the western Atlantic but also by convective rainfall events from Easterly flows and Mediterranean cyclogenetic processes, among others (Celle-Jeanton et al., 2001).

The Iberian Peninsula, located between the Atlantic Ocean and the Mediterranean Sea, is an ideal location to study the complex coupling of both Atlantic and Mediterranean climate dynamics (Celle-Jeanton et al. 2001; Gimeno et al., 2010; Gonzalez-Hidalgo et al., 2009; Trigo et al., 2006) derived from the interaction of cool north Atlantic air masses and warm and wet air from the Mediterranean region (Celle-Jeanton et al., 2001) at different time-scales (Fig. 1). In particular, periods of marked environmental variations such as the Heinrich Stadial 2 (HS2), the Last Glacial Maximum (LGM), the Heinrich Stadial 1 (HS1), the Early Holocene, or the latest Holocene are ideally suited to better understand the nature and ultimate drivers of the Atlantic-Mediterranean interactions. Although the available information about climate and environmental dynamics for the southwestern part of the Mediterranean area from the end of the last glacial cycle (MIS3-MIS2 transition) has increased considerably during the last decade (e.g., Camuera et al., 2019; Fletcher et al., 2010; Ludwig et al., 2018; Rodrigo-Gámiz et al., 2014, among others), past atmospheric patterns in this region are still unclear. In this study we explore past relationships between the west African monsoon and the western Mediterranean precipitation systems as well as the potential fluctuations in the western Mediterranean precipitation sources. These past atmospheric patterns range from high seasonality (e.g., minimum precession and/or maximum obliquity) to low seasonality periods (maximum precession and/or minimum obliquity) (Bosmans et al., 2015; Kutzbach et al., 2014; Wagner et al., 2019). Wetter stages in southern Iberia are usually registered during periods of high seasonality associated with minimum precession and/or maximum obliquity such us the early Holocene (Anderson et al., 2011; Camuera et al., 2019; Jiménez-Espejo et al., 2014; Jiménez Moreno and Anderson, 2012; Ramos-Román et al., 2018b), and are marked by enhanced winter precipitation in the Mediterranean area (Bosmans et al., 2015; Kutzbach et al., 2014; Wagner et al., 2019). These wetter stages, which are in phase with an enhanced west African summer monsoon, may be related to both a southerly Atlantic storm track trajectory and/or local Mediterranean precipitation (local cyclogenesis and/or convective precipitation) (Bosmans et al., 2015; Kutzbach et al., 2014; Wagner et al.,

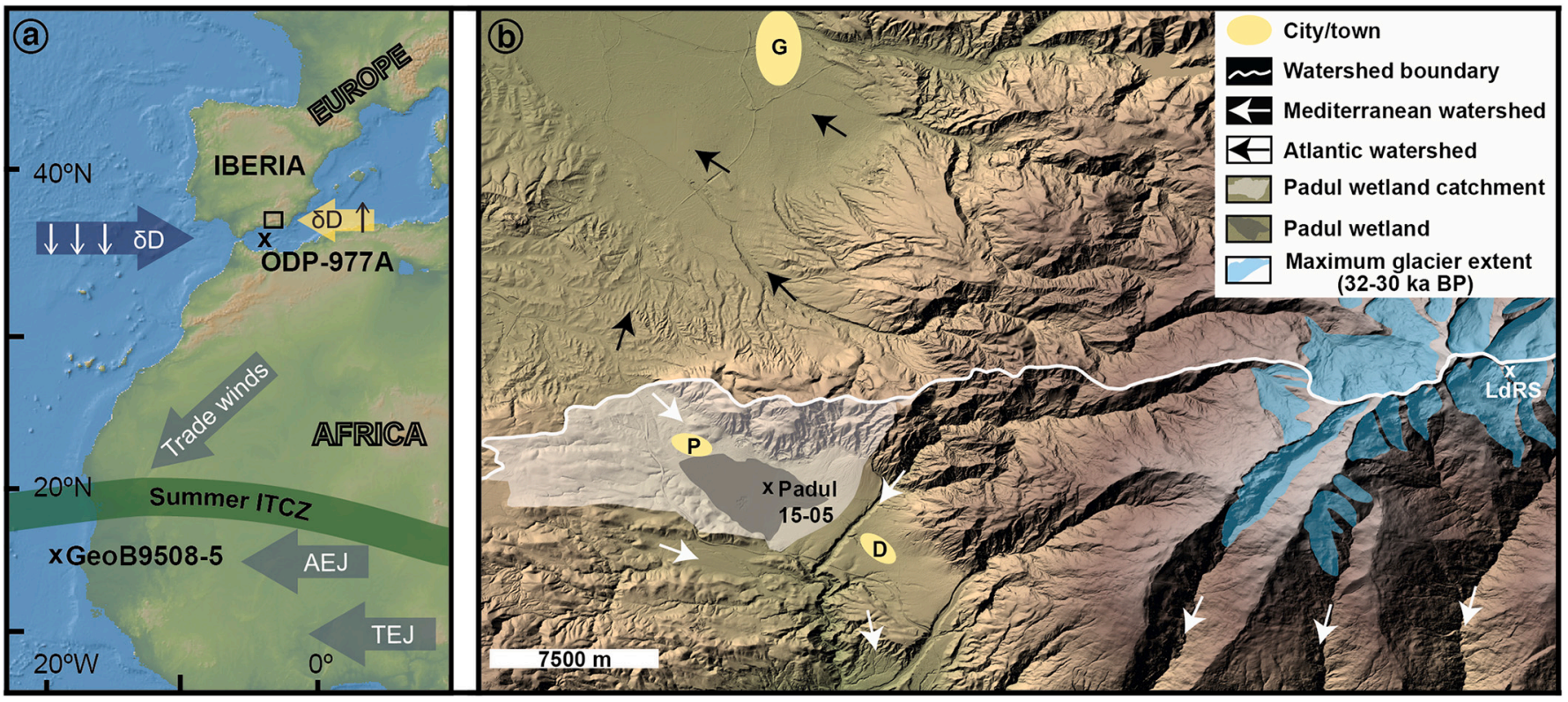

Fig. 1. Location of the Padul wetland (southern Iberia Peninsula) along with other sedimentary records mentioned in the text. Discussed records from north to south Laguna de Río Seco (LdRS) in the Sierra Nevada (southern Iberian Peninsula), ODP977A in the Alborán Sea (western Mediterranean area) (Martrat et al., 2004), and GeoB9508-5 in the continental slope off Senegal (Niedermeyer et al., 2010). a) schematic wind/moisture trajectories of the two rainfall systems discussed in the text: 1) western Mediterranean precipitation system dominated by the isotopically-depleted Atlantic moisture circulation (blue arrow) and the isotopically-enriched Mediterranean moisture (small yellow arrow) and 2) western African summer monsoon influenced by the northeasterly trade winds, the African Easterly Jet (AEJ), and the Tropical Easterly Jet (TEJ). The summer boundary of the Intertropical convergence Zone (ITCZ) is also marked. b) Location of the Padul-15-05 sediment core in the Padul wetland (726 masl) at the foothills of the Sierra Nevada, where the Laguna de Río Seco core (LdRS: 3020 masl) was recovered, along with a scheme of the main (paleo)hydrological features in the studied area. The maximum glacier extent in the last $\sim 35$ ka was taken from Palacios et al. (2016) and Palma et al. (2017). G: Granada city; P: Padul town; D: Dúrcal town. (For interpretation of the references to colour in this figure legend, the reader is referred to the web version of this article.) 
2019). For periods with low seasonality, there are discrepancies in the reconstructions of the moisture transport in the western Mediterranean. For example, while some climate simulations point towards more precipitation over the Iberian Peninsula than over northern Europe during the LGM related to a southward displacement of the Jet Stream and the Atlantic storm tracks (Laîné et al., 2009; Ludwig et al., 2016; Luetscher et al., 2015), other models and proxy-based interpretations reconstruct arid conditions in the westernmost part of the Mediterranean and southwestern Europe during this period (Ludwig et al., 2017; Ludwig et al., 2018). Additionally, although the LGM itself (from $\sim 23$ to $19 \mathrm{ka}$ BP according to Mix et al. (2001)) is considered to be the coldest period of the last glacial cycle (Hughes et al., 2013), the Iberian Peninsula registered colder and drier periods (extreme palaeohydrological conditions) during the MIS3-MIS2 transition, the HS2, or the HS1 (Camuera et al., 2019; Domínguez-Villar et al., 2013; Moreno et al., 2012; Moreno et al., 2010). Furthermore, different studies also indicated more glacier development in some periods during the MIS3 or the MIS3-MIS2 transition than during the LGM (Domínguez-Villar et al., 2013; Oliva et al., 2019). These extreme environmental conditions had a direct impact on faunal distribution in the Iberian Peninsula, forcing replacements between different Homo populations (Jiménez-Espejo et al., 2007; Ludwig et al., 2018) and inducing southward migrations of faunal assemblages. This was the case of the southernmost displacement of European woolly mammoths, documented in the Padul wetland during the HS4 and HS3 (southern Iberia) (Álvarez-Lao et al., 2009; García-Alix et al., 2012). This highlights the complex feedbacks this transitional region is experiencing and the direct environmental impacts of these abrupt climate changes.

Additionally, the identification of past sources of precipitation in the Mediterranean area, e.g. local Mediterranean (convective or cyclogenetic) moisture vs north Atlantic storm tracks, has been a matter of debate during the last decade, especially for periods of intense seasonality (Bosmans et al., 2015; Kutzbach et al., 2014; Zielhofer et al., 2017; Wagner et al., 2019). Approaches based on isotope-related proxies can play an important role unraveling this issue since different precipitation sources have distinct isotopic signatures (Celle-Jeanton et al., 2001; Dansgaard, 1964; Rindsberger et al., 1983; Rozanski et al., 1993). Nevertheless, no long-term proxy-based precipitation source (Atlantic vs Mediterranean) reconstructions exist in the western Mediterranean realm to assess whether periods of significant winter precipitation were mainly derived from Atlantic storms or local Mediterranean sources during different orbitally-forced seasonality periods of the last glacial cycle. In this study we aim to reconstruct rainfall dynamics, specifically the amount and source of precipitation in the southwestern Mediterranean area for the last $\sim 35 \mathrm{ka}$ BP by means of combining two paleohydrological proxies from a sediment core (Padul-15-05) in southern Iberia (Fig. 1). These proxies include: 1) an index based on the pollen record of humid and arid plant species (Camuera et al., 2019) that can be used as qualitative precipitation proxy (pollen precipitation index; $\mathrm{P}_{\text {index }}$ ) (Fletcher et al., 2010) and 2) hydrogen isotope compositions of plant leaf waxes ( $\delta \mathrm{D}$ of long-chain $n$-alkanes). We selected a sedimentary record in the Padul wetland, located at the foothills of the Sierra Nevada range in southern Iberia (Fig. 1), because this area has registered the alternation of lacustrine and peatland conditions throughout the last million years (Ortiz et al., 2004). The long and continuous sedimentary record of this wetland has been of special interest for paleoclimatologists for more than 60 years due to its geographic location, under the effect of both tropical and high-latitude climate systems (Menéndez-Amor and Florschütz, 1962). This privileged situation should allow the capture of past global and regional climate signals such as the interaction between Atlantic and Mediterranean paleohydrological dynamics (Camuera et al., 2019; Toney et al., 2020.

\subsection{The Padul wetland}

The Padul basin is an endorheic asymmetric graben $(\sim 3.4 \mathrm{~km}$ long
NE-SW and $\sim 3.7 \mathrm{~km}$ wide NW-SW at $\sim 726$ masl) with high and continuous subsidence in its western edge at the foothills of the Sierra Nevada. High subsidence has allowed the accumulation of more than $100 \mathrm{~m}$ of continuous detritic, carbonate, and peaty sediments at the depocenter of the basin covering, at least, the last million years (Ortiz et al., 2004, 2010; Torres et al., 2020). The detritic sedimentary infilling comes from Triassic limestones/dolostones and other low-metamorphic rocks belonging to the Alpujárride complex at the eastern and western boundaries of the catchment, and from Miocene detrital sediments (including evaporites) at the western and northwestern sides (Fontboté et al., 1980). The Padul peatland itself only extends $\sim 4.5 \mathrm{~km}^{2}$ at the depocenter of the graben, but the wetland area covers $\sim 8 \mathrm{~km}^{2}$. Its $\sim 44$ $\mathrm{km}^{2}$ catchment basin registers the lowest elevation $(\sim 720$ masl $)$ at the Padul wetland itself and reaches the highest point ( $\sim 1500$ masl) at the western face of the Sierra Nevada (Fig. 1b).

Climate in the study area is Mediterranean, characterized by a rainy cold season and summer drought (Spanish National Weather Agency AEMet Open Data, 2020). Although mean precipitation and temperature are moderate $\left(\sim 445 \mathrm{~mm} / \mathrm{yr}\right.$ and $\left.14.4{ }^{\circ} \mathrm{C}\right)$, humidity is high all year round in the wetland area and proximal catchment (Cruz Blanco, 2014; Spanish National Weather Agency - AEMet Open Data, 2020) and damp organic-rich soils predominate (Camuera et al., 2017). This local microclimate, characterized by relatively low evapotranspiration (Cruz Blanco, 2014), is favored by the topography of this intramountain (endorheic) basin at the foothills of the Sierra Nevada (ITGE-COPTJA, 1998). Water resources in the studied area are controlled by the local precipitation in the western face of the Sierra Nevada as 1) direct rainfall in the catchment, which captures runoff from $\sim 720$ to 1500 masl, and 2) groundwaters derived from meteoric waters (precipitation and annual snowmelt) at higher elevation $\sim 1500-2000$ masl, although infiltration from lower elevations, including the Padul catchment, is also present (ITGE-COPTJA, 1998; Kohfahl et al., 2008; Sprenger, 2006). The Atlantic/Mediterranean watershed boundary is located at the northern limit of the catchment, and thus, runoff from the alpine areas of the northern face of the Sierra Nevada flows into the Atlantic Ocean, following a route of more than $250 \mathrm{~km}$ via the Guadalquivir system since the Early Pleistocene (García-Alix et al., 2009). Conversely, western and southwestern alpine areas of the Sierra Nevada drain into the Mediterranean Sea via the Guadalfeo system, being the Dúrcal River, located downstream of the Padul wetland, one of the main tributaries of this system (Fig. 1b). Although Sierra Nevada registered valley glaciers in certain cold periods during the last glacial cycle, they did not occur in the Padul wetland catchment (Palacios et al., 2016; Palma et al., 2017) since the lowest elevations these glaciers reached were $\sim 2000$ and 2500 masl in the northern and southern faces, respectively, at $\sim 32-30 \mathrm{ka}$ BP (Fig. 1b) (Oliva et al., 2019).

Current vegetation at the Padul area belong to the mesomediterranean belt (from $\sim 600 / 700$ to $\sim 1400 / 1500$ masl), characterized by sclerophyllous shrublands, grasses and evergreen Quercus woodlands, among others (Valle, 2003). This local vegetation is the primary source of organic matter in the Padul peatland. This organic matter produced in the wetland itself (aquatic macrophytes and herbs) or proximal to the catchment basin (herbs, shrubs and trees) can be characterized by a greater abundance of long chain $C_{27}, C_{29}$ and $C_{31} n$ alkanes, with the latter primarily a product of upland terrestrial herbs and shrubs (Ortiz et al., 2004, 2010). A similar picture was obtained in different Sierra Nevada wetlands, showing that the production of longer chain $n$-alkanes, such as the $\mathrm{C}_{31} n$-alkane, was highest in plants growing distant from the main water pools, thus being associated with less water availability (Garcia-Alix et al., 2017). Long-term climatic fluctuations influenced the altitude and forest density configuration of the vegetation belts in the area and more open woodland and more herbs and shrubs occurred in the Padul catchment during glacial times (Camuera et al., 2019). This would not excessively affect the downcore interpretation of the $\mathrm{C}_{31} n$-alkanes, since those biomarkers mainly register terrestrial grass/herbs and shrub contributions that persisted in the area during 
both glacial and interglacial times (Ortiz et al., 2004, 2010; Camuera et al., 2019).

Sediments of the Padul basin displayed a combination of lacustrine conditions, deposition of fluvial sediments, and major development of alluvial fans, as a result of significant subsidence from $\sim 1 \mathrm{Ma}$ to 410-400 ka BP (Ortiz et al., 2004; Torres et al., 2020). This fluvial contribution was gradually reduced until $\sim 200 \mathrm{ka} B P$, as palustrine conditions increased. The evolution of the hydrological regime of the basin was probably due to the incision of the Dúrcal River on the southern edge, reducing the fluvial inputs and draining the basin (Torres et al., 2020). The last $\sim 200 \mathrm{ka}$ of the record witnessed peatland development interrupted by occasional shallow lacustrine conditions related to water level fluctuations with little influence of proper fluvial sedimentation (Ortiz et al., 2004; Camuera et al., 2018). The sedimentary record of this last stage of the Padul infilling seems to be driven by the balance between precipitation at the western face of the Sierra Nevada (also including meteoric waters at 1500-2000 masl released as groundwaters) and evaporation, ultimately controlled by insolation (Camuera et al., 2018). High lake levels (positive precipitation/evaporation balance) occurred during cold/arid glacial stages, which favored the overall deposition of carbonates and detrital inputs from the catchment (enhanced soil erosion due to overall arid conditions and scarce vegetation cover). Lower lake levels and peat deposits occurred during warmer and more humid interglacial conditions (Camuera et al., 2018, 2019). This paper focuses on the last glacial-interglacial transition (last $\sim 35 \mathrm{ka}$ ) during which alternations between carbonate/detritic (high lake levels) and peaty sediments (low lake levels) occurred (Camuera et al., 2018) (Fig. 2).

\subsection{Present precipitation dynamics in southern Iberia}

Moisture patterns in the Iberian Peninsula are mainly ruled by the westerly storm tracks and the Mediterranean dynamics. The position and intensity of the Atlantic storm tracks are controlled by north Atlantic climate dynamics, such as the North Atlantic Oscillation (NAO) generated by the dipole Azores anticyclone vs Greenland low-pressure system, while the dipole between the anticyclones in the Iberian Peninsula/ western Mediterranean and the low-pressure systems in the central/ eastern Mediterranean determine the Mediterranean atmospheric dynamics (Gonzalez-Hidalgo et al., 2009; Martin-Vide and Lopez-Bustins, 2006). Three main moisture sources interact at present in the Iberian Peninsula (Gimeno et al., 2010; Gómez-Hernández et al., 2013) following a sequence of isotopic enrichment that may be modulated by temperature and amount of precipitation: recycled moisture from the Iberian Peninsula itself, Atlantic moisture, and Mediterranean moisture (Krklec and Domínguez-Villar, 2014; Moreno et al., 2014) (Fig. 1a). Other precipitation sources that can provide depleted isotopic rainfall on the Iberian Peninsula come from cold northern continental air masses, but their contribution to the total annual pool is very low (Araguas-Araguas and Diaz Teijeiro, 2005).

Rainfall mainly occurs from September to May in southern Iberia, primarily related to the westerly circulation regime (Esteban-Parra et al., 1998). However, a Mediterranean precipitation source, mostly caused by warm isotopically-enriched convective (and sporadically cyclogenetic) moisture, occurs from spring to early autumn in the Mediterranean side of southern Iberia such as the Padul wetland $(\sim 30$ $\mathrm{km}$ from the coast) (Araguas-Araguas and Diaz Teijeiro, 2005; EstebanParra et al., 1998). This Mediterranean (isotopically-enriched) moisture

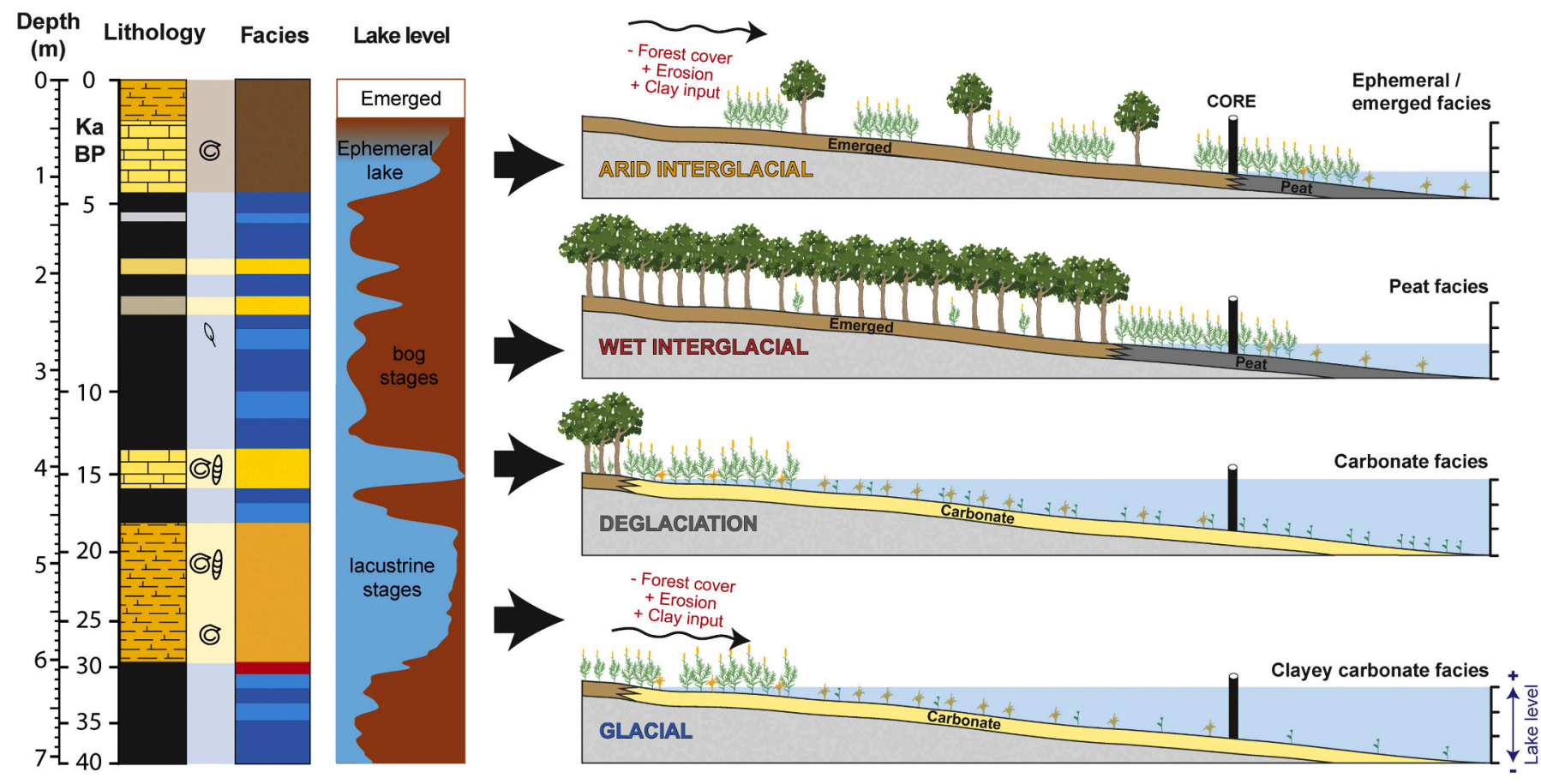

\begin{tabular}{|c|c|c|c|c|c|c|}
\hline \multicolumn{2}{|c|}{ LITHOLOGY } & \multirow{2}{*}{$\begin{array}{cl} & \text { FOSSILS } \\
& \text { Plant remains } \\
\theta & \text { Charophytes }\end{array}$} & \multicolumn{2}{|c|}{ FACIES } & \multicolumn{2}{|c|}{ MAIN VEGETATION GROUPS } \\
\hline$\exists$ Carbonate & Clay & & $\begin{array}{l}\square \text { Carbonate } \\
\square \text { Peat }\end{array}$ & $\begin{array}{l}\square \text { Clayey carbonate } \\
\square \text { Clayey peat }\end{array}$ & $\begin{array}{l}\text { Forest cover } \\
\text { (trees) }\end{array}$ & Hygrophytes \\
\hline 曰 Marl & Deat & 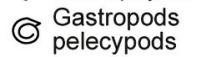 & $\square$ Brown carbonate & $\square$ Clay & Poaceae & Charophytes \\
\hline
\end{tabular}

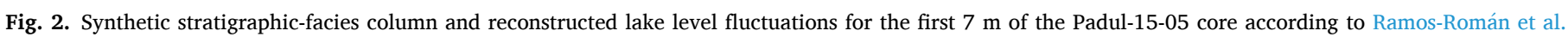

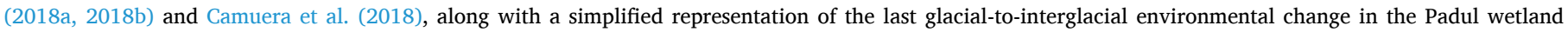
(modified for the last glacial/interglacial cycle from Camuera et al., 2018). 
source can influence the area throughout the entire year (Gimeno et al., 2010).

\section{Material and methods}

\subsection{Sediment and vegetation sampling}

The Padul-15-05 sediment core $\left(37^{\circ} 00^{\prime} 39^{\prime \prime} \mathrm{N}, 3^{\circ} 36^{\prime} 14^{\prime \prime} \mathrm{W}, 726\right.$ masl) was retrieved in July 2015 at the Padul wetland in the southern Iberian Peninsula, by means of a hydraulic percussion coring machine (Fig. 1b). It is a $42.64 \mathrm{~m}$ long core and covers the last $\sim 200 \mathrm{ka}$. The age model is based on 42 AMS-Standard radiocarbon dates, including 3 specificcompound samples, and 4 amino acid racemization samples. Although the chronology before $\sim 50 \mathrm{ka} B P$ is not well determined, it is very well constrained for the last $\sim 40 \mathrm{ka} B P$ (details on the chronology and lithology from Camuera et al. (2018)). One hundred twenty-seven sedimentary samples throughout the uppermost $\sim 670 \mathrm{~cm}$ of the Padul-1505 record (last $\sim 35.4 \mathrm{ka}$ ) were selected for organic geochemical analyses (Fig. S1). Pollen data of deciduous Quercus, Ephedra, Artemisia, and Amaranthaceae from 262 samples of the uppermost $675 \mathrm{~cm}$ (last $\sim 36$ ka) of the Padul-15-05 record analysed by Camuera et al. (2019) and Ramos-Román et al. (2018a, 2018b) were used to calculate the Pollen Precipitation Index $\left(\mathrm{P}_{\text {index }}\right)=\log _{10}[Q$. deciduous $/(E+A+\mathrm{A})]$. This index, comparing humid vs arid plant species, has been successfully used to qualitatively track precipitation oscillations in the western Mediterranean region (Fletcher et al., 2010).

Twenty-three of the most representative plants in the Padul wetland were sampled twice during 2016:1) early May (middle growing season), as representative of the winter/spring precipitation and 2) late September (end of growing season), after the typical Mediterranean summer drought. Similar plants were sampled in both field-campaigns in order to compare their isotopic signatures. This sampling considered the Spanish water year from October 1st to September 30th of the next year.

\subsection{Water sampling and isotope analyses}

Fifty-six water samples were taken between May 2016 and December 2020 from the Padul wetland (spring and lake sources), sealed, and coldstored at $4{ }^{\circ} \mathrm{C}$. Afterwards, they were analysed by means of laser spectrometry-based analyzers: Picarro L2140-i at the Potsdam GFZ Helmholtz Centre, Picarro L2130-i at the University of Málaga, and Picarro L2140-i at the University of Granada. Results are expressed in delta-notation (\%o) relative to the Vienna Standard Mean Ocean Water (VSMOW) for oxygen $\left(\delta^{18} \mathrm{O}\right)$ and hydrogen $\left(\delta^{2} \mathrm{H}\right.$ or $\left.\delta \mathrm{D}\right)$. Analytical uncertainty is $\pm 0.2 \%$ or $\delta^{18} \mathrm{O}$ and $\pm 0.4 \%$ for $\delta \mathrm{D}$. The standards used in calibration at the Potsdam GFZ Helmholtz Centre, the University of Málaga, and the University of Granada were IAEA standards including VSMOW2 and GISP.

\subsection{Organic geochemical analyses}

The total lipid content was extracted from $\sim 1 \mathrm{cc}$ of sediment with an accelerated solvent extractor system Thermo Scientific ${ }^{\mathrm{TM}}$ Dionex $^{\mathrm{TM}}$ ASETM $^{\mathrm{T}} 350$ using a mixture of dichloromethane and methanol (9:1). In addition, the total lipid content of twenty-three plant samples were extracted by mean of sonication and a mixture of dichloromethane: methanol (9:1). The aliphatic fraction (including the $n$-alkanes) was eluted with hexane and separated by means of manual silica gel chromatography following the procedure described in Rach et al. (2020). The $n$-alkanes were identified and quantified using Gas Chromatography flame ionization detection and mass spectrometry (GC-FID and GC-MS) following Rach et al. (2020) settings. Another purification step using pre-activated $\mathrm{Cu}$ powder (to remove potential sulphurs) and preactivated $\mathrm{AgNO}_{3}$ (to separate saturated and unsaturated hydrocarbons) was performed in ten samples to assess if this extra step would significantly improve the $n$-alkane signal for hydrogen isotope analyses. Since there were no important differences in the obtained results, this extra purification was not applied to all the samples.

Forty-seven samples extracted from the Padul-15-05 core were discarded since either their $n$-alkane concentration was below the threshold for hydrogen isotope analyses or the chromatogram exhibited a significant background and/or unresolved complex mixture (UCM) that would affect the isotope measurements (Fig. S1). Thus, only eighty $n$ alkane samples extracted from the sediments and twenty-three $n$-alkane plant extracts were measured by GC-IRMS. $\delta \mathrm{D}$ analyses of $n$-alkanes were conducted on a Thermo Fisher Scientific MAT $253^{\mathrm{TM}}$ Isotope Ratio Mass Spectrometer coupled via a GC IsoLink operated at $1420{ }^{\circ} \mathrm{C}$ to a Thermo Fisher Scientific TRACE GC equipped with a HP- 5 ms column ( $30 \mathrm{~m}, 0.25 \mathrm{~mm}, 1 \mu \mathrm{m}$ ) against calibrated $\mathrm{H}_{2}$ reference gas. The concentration of the $n$-alkanes in the sediment samples was adjusted to 100 $\mathrm{ng} / \mathrm{ul}$ for the target compounds. Each sample was measured in duplicate. Accuracy and precision were controlled by a lab internal $n$-alkane standard calibrated against the A4-Mix isotope standard (A. Schimmelmann, University of Indiana) every six measurements and by the daily determination of the $\mathrm{H}_{3}$ factor. Measurement precision was determined by calculating the difference between the analysed values of each standard measurement and the long-term mean of standard measurements, which yielded a $1 \sigma$ error of $3 \%$. $\mathrm{H}_{3}$ factors varied between 5.0 and 5.2. Hydrogen isotopes of mid-chain $n$-alkanes were not analysed due to the presence of a significant UCM coeluting with these compounds. This UCM co-elution even affected the $\delta \mathrm{D}$ signal of the $\mathrm{C}_{29} n$ alkane in some of the samples, especially in Holocene samples where peaty and clay/carbonate (ephemeral lake) facies predominate. This is clearly observed in four samples (Figs. S1, S2) where the $\mathrm{C}_{29}$ n-alkane exhibited heavily (and abrupt) enriched values respect to the $C_{31} n$ alkane. Considering this potential bias in the hydrogen isotopic signal of the $\mathrm{C}_{29} n$-alkane and that previous studies in the Padul wetland suggest that the potential contribution of macrophytes to the $C_{31} n$-alkane pool in the sediments was very low (Ortiz et al., 2004, 2010), the discussion of the isotopic signature of the long-chain $n$-alkanes in the Padul-15-05 record will only focus on the $\mathrm{C}_{31}$ homologue. Examples of IRMS chromatograms for the different facies are shown in Fig. S2.

\subsection{Data analyses}

Long-term dynamics throughout the isotopic signal of the Padul-15$05 n$-alkane record have been assessed after correcting the potential effect of sea-water isotopic changes from glacial (ice-sheet ${ }^{16} \mathrm{O}$ sequestration) to interglacial (ice-sheet ${ }^{16} \mathrm{O}$ release) periods (Dansgaard, 1964) on the isotopic composition of the moisture sources following Niedermeyer et al. (2010) approach $\left(\delta \mathrm{D}_{\mathrm{C} 31_{\text {_ice-c }} \mathrm{c}}\right.$. This ice volume correction is almost negligible for the latest Holocene.

The ages of the different records have been interpolated to the same age-intervals to enable their correlation. A sample-to-sample Pearson correlation captures the raw relationship between different records, whereas a 5-point moving average allows the comparison of long-term oscillations. Additionally, data were also fitted to a smoothing spline by means of a sequence of third-order polynomials continuous up to the second derivative by means of Past 4.03 software (Hammer et al., 2001) in order to facilitate the long-term graphical comparisons between different records.

A z-score, mean and standard deviation normalization, was used to facilitate the comparison of variables with different units, means, and/or standard deviations.

\section{Results}

\subsection{Water isotopes in the Padul wetland}

The isotopic composition of the measured spring water samples for the years 2016, 2018, 2019, and 2020 was very homogeneous, ranging 
from $-62.4 \%$ to $-53.5 \%$ with a mean value of $-56.2 \pm 1.8 \%$ for hydrogen isotopes, and from $-9.9 \%$ to $-8.1 \%$ with a mean value of $-8.7 \pm 0.4 \%$ for oxygen isotopes (Table S1). Limited available spring data for this region [data from February 2004 to April 2005 (Kohfahl et al., 2008; Sprenger, 2006)] agree with those numbers, showing values ranging from $-57.1 \%$ to $-52.5 \%$ with a mean value of $-55.1 \pm 1.6 \%$ for hydrogen isotopes, and from $-8.6 \%$ to $-8.1 \%$ with a mean value of $-8.4 \pm 0.2 \%$ for oxygen isotopes (Table S1). The combination of both datasets showed a general mean of $-56.0 \pm 1.8 \%$ for hydrogen isotopes and $-8.7 \pm 0.4 \%$ for oxygen isotopes in Padul spring waters.

The isotopic composition of lake water was more variable, ranging from $-56.9 \%$ to $-31.4 \%$ with a mean value of $-46.2 \pm 8.5 \%$ for $\delta \mathrm{D}$ values, and from $-9.1 \%$ o to $-3.5 \%$ with a mean value of $-6.7 \pm 1.8 \%$ for $\delta^{18} \mathrm{O}$ values (Table S1). Among the three sampling points, the pond near a spring (spot 1 ) yielded the most negative and constant values throughout these four years $\left(\delta \mathrm{D}=-55.3 \pm 0.4 \%\right.$ and $\delta^{18} \mathrm{O}=-8.6 \pm$ $0.3)$. These values are in the same range as for the spring waters. The other two spots, located in the main lake shore, show more isotopicallyenriched values: spot 2) $\delta \mathrm{D}=-42.1 \pm 7 . \%$ and $\delta^{18} \mathrm{O}=-5.8 \pm 1.4 \%$, and spot 3$) \delta \mathrm{D}=-40.4 \pm 6.1 \%$ and $\delta^{18} \mathrm{O}=-5.5 \pm 1.4 \%$ (Table S1). This enrichment is especially evident in samples from September 2016 and 2020 (end of summer drought) where both spots show the highest isotopic values ranging from $-36.5 \%$ to $-31.4 \%$ ( $\delta \mathrm{D})$ and from $-4.8 \%$ to $-3.5 \%$ o $\left(\delta^{18} \mathrm{O}\right)$. The isotopic composition of the lake water spot 1 (near the water spring) for September 2016 and $2020(-55.5 \pm 0.1 \%$ ( $\delta \mathrm{D})$ and $-8.6 \pm 0.1 \%$ o $\left(\delta^{18} \mathrm{O}\right)$ did not display this isotopic enrichment.

\subsection{Vegetation leaf wax hydrogen isotopes in the Padul wetland}

The most abundant $n$-alkanes in samples from trees and aquatic plants were the $\mathrm{C}_{27-29}$ homologues, although some shorter chained $n$ alkanes could be dominant in aquatic plants such as Myriophyllum and bryophytes. Herbs and shrubs primarily displayed the highest concentrations of the $\mathrm{C}_{29}$ and $\mathrm{C}_{31} n$-alkanes; nevertheless, the $\mathrm{C}_{27} n$-alkane predominated in some cases, such as in Rosaceae (shrubs) and Liliaceae (herbs). These figures were in the range of the previously published data for vegetation in the same region (Ortiz et al., 2010; Garcia-Alix et al., 2017). The averaged concentrations of the $C_{27}, C_{29}$ and $C_{31} n$-alkanes in the studied aquatic plants were $\sim 230,120$, and 25 micrograms per gram of dry plant $\left(\mu \mathrm{gdp}^{-1}\right)$, respectively, only representing $\sim 5-6 \%$ of the total (aquatic and terrestrial) $n$-alkanes concentrations (Table S2).

Hydrogen isotope composition of the $C_{29} n$-alkanes $\left(\delta D_{C 29}\right)$ of the main plant groups surrounding the Padul wetland exhibit values ranging from $-217 \%$ to $-124 \%$ with a mean value of $-179 \pm 27 \%$ in early May 2016. Although $\delta \mathrm{D}_{\mathrm{C} 29}$ values overlap, they are slightly less negative in late September 2016, ranging from $-213 \%$ o to $-140 \%$ o with a mean value of $-172 \pm 23 \%$ o (Table S3). However, no significant statistical differences were obtained between both groups $(p>0.05)$ after applying a T-student test. The hydrogen isotope composition of the $\mathrm{C}_{31} n$-alkanes $\left(\delta D_{\mathrm{C} 31}\right)$ shows similar overall patterns, ranging from $-212 \%$ to $-119 \%$ o with a mean value of $-179 \pm 29 \%$ for early May 2016 and from $-220 \%$ to $-143 \%$ with a mean value of $-172 \pm 21 \%$ for late September 2016 (Table S3). No significant statistical differences were obtained between both groups $(\mathrm{p}>0.05)$ after applying a T-student test. The average value of both seasons for both homologues is identical within uncertainties: $-178 \pm 21\left(\delta \mathrm{D}_{\mathrm{C} 29}\right)$ and $-177 \pm 21\left(\delta \mathrm{D}_{\mathrm{C} 31}\right)$ (Table $\left.\mathrm{S} 3\right)$.

\subsection{Sedimentary leaf wax hydrogen isotopes in the Padul-15-05 record}

The $\delta \mathrm{D}$ values of the $\mathrm{C}_{29}$ and $\mathrm{C}_{31} n$-alkanes in the Padul-15-05 record covary for the last $\sim 35 \mathrm{ka} \mathrm{BP}(r=0.73 p<0.0001)$. Nevertheless, $\delta \mathrm{D}_{\mathrm{C} 29}$ record shows more abrupt oscillations, potentially caused by the coelution of a UCM in some of the samples, especially for Holocene ones. $\delta D_{\mathrm{C} 29}$ values range from $-235 \%$ to $-145 \%$ with a mean value of $-197 \pm 16 \%$ whereas $\delta \mathrm{D}_{\mathrm{C} 31}$ values range from $-228 \%$ to $-171 \%$ with a mean value of $-204 \pm 12 \%$ (Fig. S1). The most negative values in both records are registered between $\sim 15.5$ and $5 \mathrm{ka}$ BP. Values corrected for ice volume changes registered less amplitude in the variations (Fig. S1). Especially negative values are observed at $\sim 10.4$ ka $\mathrm{BP}\left(\delta \mathrm{D}_{\mathrm{C} 29}=\right.$ $-227 \%$ and $\delta \mathrm{D}_{\mathrm{C} 31}=-227 \%$ o $)$ and at $\sim 7.2 \mathrm{ka} \mathrm{BP}\left(\delta \mathrm{D}_{\mathrm{C} 29}=-235 \%\right.$ and $\delta \mathrm{D}_{\mathrm{C} 31}=-228 \%$ ). Highest $\delta \mathrm{D}$ values of the record occur in two periods, $1)$ the period from $\sim 30$ to $15.5 \mathrm{ka} \mathrm{BP}$, with peaks at $\sim 25.8 \mathrm{ka} \mathrm{BP}\left(\delta \mathrm{D}_{\mathrm{C} 31}\right.$ $=-177 \%$ ) and at $\sim 23.2 \mathrm{ka} \mathrm{BP}\left(\delta \mathrm{D}_{\mathrm{C} 29}=-183 \%\right.$ ond $\delta \mathrm{D}_{\mathrm{C} 31}=-184 \%$ ), and 2) the period covering the last $5 \mathrm{ka} \mathrm{BP}$, which also registers the highest absolute $\delta \mathrm{D}$ values of the record with peaks at $4.6 \mathrm{ka} \mathrm{BP}\left(\delta \mathrm{D}_{\mathrm{C} 29}\right.$ $=-145 \%$ and $\left.\delta \mathrm{D}_{\mathrm{C} 31}=-171 \%\right)$, at $3.6\left(\delta \mathrm{D}_{\mathrm{C} 29}=-164 \%\right)$, and at $\sim 0.8$ ka BP $\left(\delta \mathrm{D}_{\mathrm{C} 29}=-146 \%\right.$ and $\delta \mathrm{D}_{\mathrm{C} 31}=-181 \%$ ) .

\section{Discussion}

4.1. Control on leaf wax hydrogen isotope ratios in the Padul-15-05 record

\subsubsection{Water resources at the Padul wetland: Sources and isotopic} signatures

The ultimate source of water in the Padul wetland is the precipitation that derives from either local catchment rainfall ( $\sim 700-1500$ masl) or from higher elevations ( $\sim 1500-2000$ masl) in the Sierra Nevada that reaches the basin as spring groundwaters (ITGE-COPTJA, 1998; Kohfahl et al., 2008). The isotopic composition of the precipitation in the Granada area at $\sim 700$ masl, (weighted mean $\delta \mathrm{D}=\sim 42.5 \%$ ) obtained from five years precipitation (Raya Garrido, 2003) is accurately summarized by the Online Isotopes in Precipitation Calculator (OIPC) model at similar elevation at the Padul wetland (Bowen, 2020) (Fig. S3). The simulated weighted mean hydrogen isotopic composition of annual precipitation at the highest elevation of the Padul wetland catchment $(\sim 1500$ masl) is $\sim-54 \pm 2 \%$ (Bowen, 2020 ); thus, the hydrogen isotopic signature of the effective runoff contribution to the Padul basin would be an intermediate value between $\sim-54$ and $-42.5 \pm 2 \%$. The isotopic composition of spring groundwaters in the Padul wetland is also closely connected to the annual precipitation of the recharge area at $\sim 1745 \pm 200$ masl, according to the local isotope fractionation equation (Kohfahl et al., 2008). This range agrees with the actual main recharge area of the aquifer, between 1500 and 2000 masl in the western face of Sierra Nevada, although infiltration at lower elevations also exists due to the geological complexity of this area (ITGE-COPTJA, 1998). Groundwater residence time is around one year, but in any case, lower than decadal scale according to the ratio recharge/outflow (Fletcher et al., 2012). This would remove any potential seasonal isotopic effect of precipitation (Kohfahl et al., 2008) and provides a relative constant hydrogen isotopic composition of spring waters in the Padul area $(\delta \mathrm{D}$ from 2004 to $2020-56.0 \pm 1.8 \%$ ), which agrees with the modelled weighted hydrogen isotope composition of the annual precipitation for the main recharge area of the aquifer ( $\delta \mathrm{D}$ ranging from -61 to $-54 \pm$ $2 \%$, Bowen (2020)). Groundwaters as spring and phreatic waters recharge the Padul wetland waters at $\sim 720$ masl, but they barely emerge in other points of the catchment (ITGE-COPTJA, 1998). Lake and wetland areas near springs did not show any isotopic enrichment throughout different seasons, averaging annual isotopic contributions, but lake surface/shore waters displayed more enriched values due to either more contribution from warm season rainfall or evaporative processes on surface lake waters, reaching $\delta \mathrm{D}$ values close to $-30 \%$ (Table S1). In any case, both runoff and groundwater share the same origin: precipitation in the western face of the Sierra Nevada, and thus are controlled by the same drivers, providing an averaged signal of the (multi)annual meteoric contribution in the studied area. The sedimentary $n$-alkanes accumulated in the Padul wetland would indeed average this (multi)annual mixture minimizing any occasional bias on the precipitation isotopes in the long-term timescale discussed in this study.

In general, the isotopic composition of precipitation mainly depends on the amount of precipitation, humidity, air temperature, and precipitation source (Dansgaard, 1964; Rozanski et al., 1993). The correlation 
between weighted monthly hydrogen isotope composition of precipitation in the Padul area (Bowen, 2020), precipitation amount, and temperatures (Spanish National Weather Agency - AEMet Open Data, 2020) points to a high control of temperature and precipitation amount on the isotopic composition of precipitation $\left(r=-0.78-\delta \mathrm{D}_{\text {precipitation }}\right.$ vs precipitation amount and $0.92-\delta \mathrm{D}_{\text {precipitation }}$ vs temperature, $p<0.0001$ ) highlighting a seasonal control (Fig. S3). However, the potential effects of temperature and precipitation amount on the isotopic composition of precipitation are unknown in longer time-scales (e.g., LGM, deglaciation, or Holocene) due to the lack of long-term observational time-series.

The potential influences of different precipitation sources in the Padul-Granada area were assessed throughout the above-mentioned five-year period with available isotopic precipitation data by calculating the local backward trajectories of the different precipitation events (Figs. S4, S5). Overall, the precipitation events observed in these five years mainly came from (north and tropical) Atlantic moisture sources during the entire year. This source dominates during the cold season. In addition, some slight contribution from Mediterranean vapor sources to local precipitation is observed all the year round, being especially high from spring to autumn (Figs. S4, S5). Monthly precipitation in the Padul - Granada - Sierra Nevada area follows a similar pattern showing more isotopically enriched values during the warm season (May-October) (Raya Garrido, 2003; Bowen, 2020; Toney et al., 2020, in agreement with lower precipitation amount, except for October that usually registers higher precipitation (Spanish National Weather Agency - AEMet Open Data, 2020) (Fig. S3). In this way, mean annual $\delta D$ data in the Padul-Granada area at $\sim 700$ masl $(\sim-42 \pm 2 \%$ o obtained from real precipitation records (Raya Garrido, 2003) and the OIPC model (Bowen, 2020) can therefore be explained by a mixture of Atlantic (endmember value $\sim-56 \pm 3 \%$ ) and Mediterranean (endmember value $\sim-25 \pm 2$ ) moisture sources, a mixture typical of the western Mediterranean area (Celle-Jeanton et al., 2001) (Fig. 1). The same can be stated for higher areas of the Sierra Nevada Toney et al., 2020, and thus for the rechage area of Padul groundwaters, after correcting by the local isotopic elevational gradient (Kohfahl et al., 2008).

\subsubsection{The hydrogen isotope composition of leaf waxes as a}

\section{paleohydrological proxy at the Padul wetland}

Long time-scale fluctuations of these hydrological features in the study area can be assessed by means of the hydrogen isotopic composition of plant leaf waxes stored in the sediments, since it mainly depends on the source water used by plants (Sachse et al., 2012). Other factors such as plant physiology and evapotranspiration processes can produce an extra fractionation in the isotopic signal that plant leaf waxes eventually register, but without totally overriding the original source water signal (Feakins and Sessions, 2010; Rach et al., 2017; Sachse et al., 2012). In this study we focus on the $C_{31} n$-alkanes, given that this and previous works showed that this homologue is primarily produced by terrestrial shrubs and herbs in the Padul wetland (Table S2) (Ortiz et al., 2004, 2010). This approach minimizes any potential bias by aquatic plant contribution to the biomarker record and result in a more robust paleohydrological interpretation of the Padul-15-05 record. Plant communities in southern Iberia usually display a multi-seasonal growing pattern with the most important growing season in spring-early summer, but some plant growth is also detected in autumn-winter (Pérez Latorre and Cabezudo, 2002). Since there are no statistical differences between the $n$-alkane isotopic signature of late spring and early autumn vegetation in the study area, Padul wetland plants would provide an averaged isotopic signal of the entire year of the water stored in the soil. This soil water derives from precipitation in the catchment and in the recharge area of the aquifer, averaging the precipitation signal of the western face of the Sierra Nevada from $\sim 700$ to 2000 masl. This signal would be independent of that of the lake (surface) waters that can be affected by different evaporation patterns, as it is evidenced by the obtained isotopic results from different water sources in the Padul wetland (Table S1 and Fig. S3).
As mentioned above, sedimentary organic matter in the Padul wetland is primarily accumulated as peat and mainly comes from the wetland itself and proximal catchment (Camuera et al., 2018, 2019; Ortiz et al., 2004, 2010; Ramos-Román et al., 2018a, 2018b; Torres et al., 2020). This can also be applied to the leaf waxes, since previous works assume the same local $n$-alkane source, at least, for the last $\sim 200$ ka (Ortiz et al., 2004, 2010). This catchment-averaged $n$-alkane contribution registered in the lacustrine/peaty sediments of Padul $\left(\mathrm{C}_{31} n\right.$-alkanes in this study) would provide an accurate multi-annual picture of the hydrogen isotope composition of leaf waxes in the area, and thus, of the hydrology (Sachse et al., 2004, 2012). This averaged $C_{31} n$-alkane mixture is dominated by local terrestrial sources, thus minimizing the effect of any potential allochthonous $\mathrm{C}_{31} n$-alkane inputs to this high productive wetland (e.g., aeolian inputs from oligo-mesotrophic alpine Sierra Nevada areas) or occasional contributions from aquatic plants.

A scenario of local humid microclimate with low evapotranspiration (Cruz Blanco, 2014; Spanish National Weather Agency - AEMet Open Data, 2020) can be also assumed in the past, and potential long-term evaporative effects on the $35 \mathrm{ka} \delta \mathrm{D}_{\mathrm{C} 31}$ record can be ruled out. This is interpreted since the highest lake water levels, deduced from geochemical and pollen proxies (Camuera et al., 2018; Camuera et al., 2019), agree with the highest isotopic values (except for the last $\sim 3 \mathrm{ka}$ ) and are coeval with the lowest warm-season insolation at $37^{\circ} \mathrm{N}$ when reduced evaporation was expected, and the other way around, the lowest isotopic values agree with the highest warm-season insolation at $37^{\circ} \mathrm{N}$ when enhanced evaporation was presumed (Camuera et al., 2019) (Fig. 3 a,b,h). These de-coupled trends between the hydrogen isotopic composition of leaf waxes and lake water levels, mainly controlled by the balance between local precipitation-groundwater discharge (this latter derived from annual meteoric waters at higher elevations) vs evaporation, support previous evidences suggesting that the $C_{31} n$ alkane primarily registers a terrestrial signal (herbs and shrubs) (Ortiz et al., 2004, 2010) instead of a mix of aquatic/terrestrial contribution. Therefore, a significant input of $\mathrm{C}_{31} n$-alkanes from aquatic plants to the Padul-15-05 sedimentary record can be discarded.

All these evidences suggest that the Padul-15-05 $\delta D_{\mathrm{C} 31}$ record is a reliable paleo-rainfall archive in southern Iberia, yet its specific paleoenvironmental signal has to be accurately contrasted with long-term paleorecords. In this regard, there is no significant correlation between the $\delta \mathrm{D}_{\mathrm{C} 31 \text { ice-c }}$ data from Padul-15-05 and temperature records at regional scale, e.g., sea surface temperatures (SST) in the nearby Alborán Sea (Martrat et al., 2004), $r=-0.19 p>0.1$ (Fig. 3d, h), and hemispheric scales, e.g., the Greenland NGRIP $\delta^{18} \mathrm{O}$ ice record (Andersen et al., 2004), $r=-0.07 p=0.5$ (Fig. 3e, h). Given that the relationship between the isotopic composition of precipitation and temperatures was expected to be positive (Dansgaard, 1964(Rozanski et al., 1993), also in the studied area (García-Alix, 2015), these high $p$ values along with the opposite signal in the correlation would indicate either a lack of significant temperature control on the Padul-15- $05 \delta \mathrm{D}_{\mathrm{C} 31}$ record and/or a reduced temperature effect overprinted by more dominant drivers. Conversely, a statistically significant anticorrelation is observed between the $\delta \mathrm{D}_{\mathrm{C} 31 \text { _ice-c }}$ and a pollen-based precipitation proxy index $\left(\mathrm{P}_{\text {index }}\right)$ of the same record $(r=-0.43 p=0.0002$ for raw data and $r=-0.59 p<0.0001$ for a 5-point moving average showing long-term trends, which would explain up to $35 \%$ of the variance), pointing towards a connection between the isotopic composition of precipitation and rainfall amount at long-term time-scales. The amount effect primarily occurs throughout the year at low latitudes, mainly during summer at mid latitudes, and is inexistent at high latitudes and polar areas. This isotopic fractionation is especially amplified in light rains due to evaporation and isotopic exchange between environmental vapor and falling drops (Dansgaard, 1964). In this way, intense evaporation of the falling drops during dry periods (e.g., glacial periods) in the Padul wetland would cause an extra decrease in precipitation amount and an isotopic enrichment, and the other way around, as can be observed in the anticorrelation between long-term trends of $\delta \mathrm{D}_{\mathrm{C} 31}$ and 


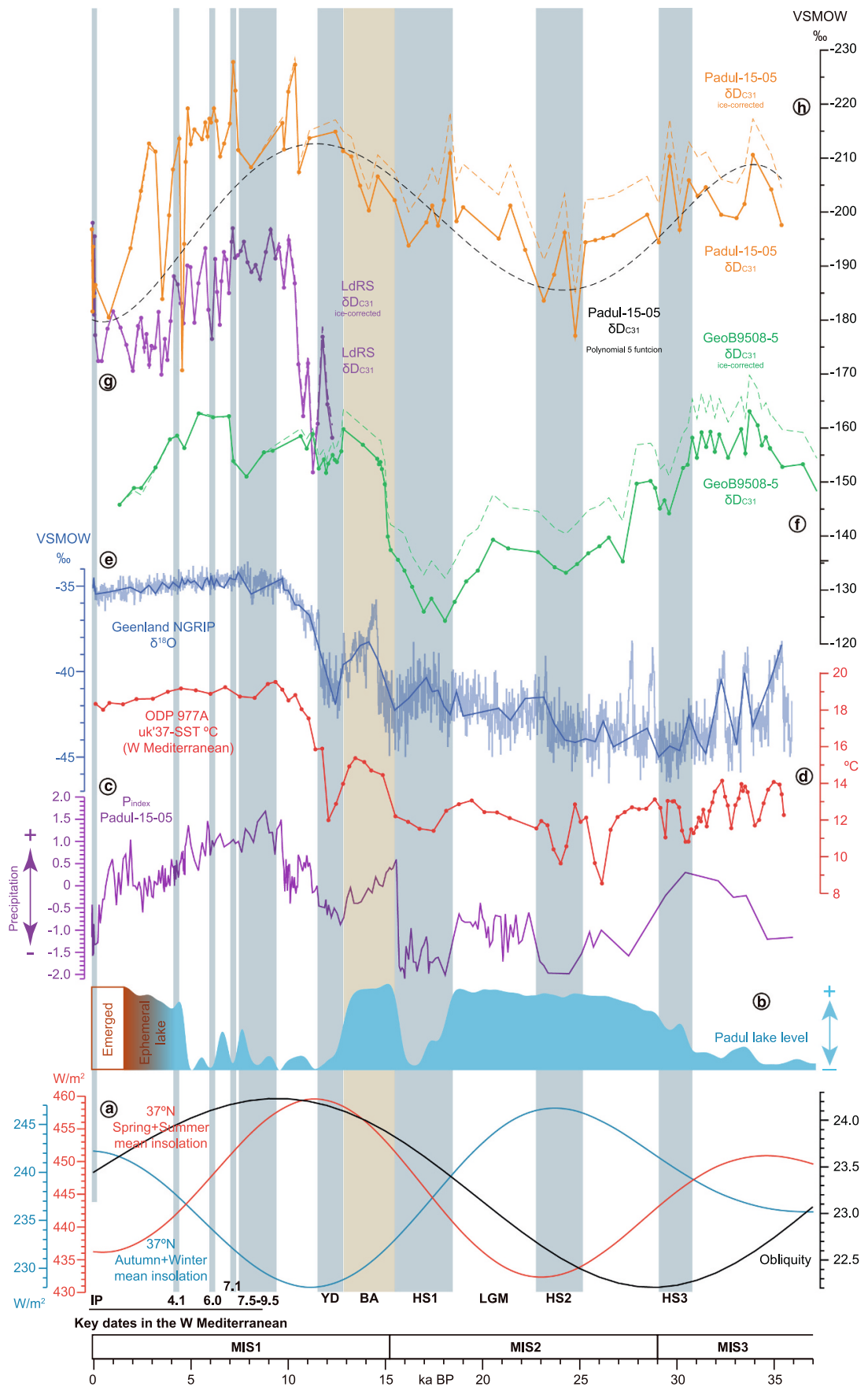

Fig. 3. (a) Warm season (Spring+Summer) vs cold season (Autumn+Spring) insolation at $37^{\circ} \mathrm{N}$ and obliquity (Laskar et al., 2004); (b) Padul wetland lake level calculated from different geochemical proxies (Camuera et al., 2018); (c) pollen precipitation index $\left(\mathrm{P}_{\text {index }}\right)$ calculated from the Padul15-05 pollen record (Camuera et al., 2019); (d) alkenone unsaturation index $\mathrm{U}^{\mathrm{k}}{ }_{37}-\mathrm{SST}{ }^{\circ} \mathrm{C}$ from the ODP 977A site in the western Mediterranean (Martrat et al., 2004); (e) Oxygen isotopic composition of the NGRIP ice core (Andersen et al., 2004; Rasmussen et al., 2020); (f) GeoB9508-5 $\delta D_{\mathrm{C} 31}$ record (green solid line), corrected for ice volume effects (green dashed line) at $\sim 15^{\circ} \mathrm{N}$ in the continental slope off Senegal (Niedermeyer et al., 2010); (g) Laguna de Río Seco (LdRS) $\delta \mathrm{D}_{\mathrm{C} 31}$ record (purple solid line), corrected for ice volume effects (purple dashed line) at 3020 masl in the Sierra Nevada (S Iberia) Toney et al., 2020 (h) this study: Padul-15-05 $\delta \mathrm{D}_{\mathrm{C} 31}$ record (orange solid line), corrected for ice volume effects (orange dashed line); Padul-15-05 $\delta \mathrm{D}_{\mathrm{C} 31}$ record fitted with a fifth degree polynomial function (black long dashed line). Acronyms: MIS, Marine Isotope Stage; HS, Heinrich Stadial; LGM, Last Glacial Maximum; BA, Bølling-Allerød; YD, Younger Dryas; IP, Industrial Period. (For interpretation of the references to colour in this figure legend, the reader is referred to the web version of this article.) the precipitation amount deduced from the $\mathrm{P}_{\text {index }}$ in the Padul-15-05 record.

In summary, the isotope precipitation pattern in the Padul wetland follows the general model described in other Mediterranean areas of the Iberian Peninsula (Araguas-Araguas and Diaz Teijeiro, 2005; CelleJeanton et al., 2001; Krklec and Domínguez-Villar, 2014; Moreno et al., 2014) and is influenced by the different atmospheric dynamics that affect precipitation in southern Iberia [Atlantic (e.g., NAO) vs Mediterranean dynamics], depending on the season of the year (EstebanParra et al., 1998; Gonzalez-Hidalgo et al., 2009; Oliva and Moreno, 2008). Present-day precipitation patterns in the Iberian Peninsula suggest that past fluctuations in the predominance of a specific precipitation source would also indicate a shift in the main rainy months (e.g., shift from autumn-winter to late winter-early spring). In addition, the amount of precipitation in southern Iberia, at least partially, influenced the long- term rainfall isotopic signal, and can be tracked in the past by means of the Padul-15-05 $\delta D_{C 31}$ record. This amount effect would enhance the isotopic enrichment of precipitation in the study area during extreme arid events such as glacial periods. The above discussed evidences suggest that other potential drivers of long-term fluctuations in the hydrogen isotopic composition of the $\mathrm{C}_{31} n$-alkanes, namely temperature or local evapotranspiration, would not have overridden the precipitation amount and source signal in the Padul wetland. Nevertheless, their occasional influence cannot be totally discarded.

\subsection{Padul-15-05 $\delta D_{C 31}$ as a recorder of past precipitation in the western Mediterranean}

Paleohydrological reconstructions performed by means of a combination of precipitation proxies from diverse origins can disentangle the 
different proxy specific controlling factors. The present study follows this approach by means of the combination of both a pollen-based precipitation reconstruction and $\delta \mathrm{D}_{\mathrm{C} 31}$ data in the Padul area in order to understand long-term past precipitation patterns in the western Mediterranean area during the last $\sim 35 \mathrm{ka} \mathrm{BP}$. This proxy combination (Fig. 3) along with present day (Fig. 1, S3, S4, and S5) and past longterm patterns (Figs. 3,4 ) suggest that at this location the $\delta D_{\text {wax }}$ records mainly register rainfall amount likely modified by changes in the precipitation source (Atlantic vs Mediterranean). The Holocene $\delta D_{\text {wax }}$ record of a neighboring alpine wetland (Laguna de Río Seco, LdRS) within the Sierra Nevada mountain range supports this interpretation (Fig. $3 \mathrm{~g}, \mathrm{~h}$ ), as it depicts the same $\delta \mathrm{D}_{\text {wax }}$ patterns as the ones observed in the Padul record (except its absolutes values) with an abrupt change in the $\delta \mathrm{D}_{\mathrm{wax}}$ trend during the middle-late Holocene related to a decrease in precipitation amount and more influence of local Mediterranean dynamics Toney et al. (2020) coeval with the demise of the African Humid Period (AHP) and the end of the wettest phase in the western Mediterranean area (Anderson et al., 2011; Jiménez-Espejo et al., 2014). Although both records display overall similar trends, the relative isotopic enrichment of the LdRS record with respect to the Padul-15-05 core can be explained by specific features of its catchment, covered with snow most of the year, southward oriented, and with scarce patchy tundra vegetation only growing during the late spring-summer under the influence of warm season precipitation (high Mediterranean moisture contribution) along with the isotopic enrichment of catchment waters. Additionally, another recent study based on hydrogen isotopes of leaf waxes from a sediment core in the Alborán Sea described highfrequency changes in the source of precipitation in southern Iberia related to the interaction between Atlantic and Mediterranean atmospheric dynamics (Schirrmacher et al., 2020).

The high $\delta \mathrm{D}_{\mathrm{C} 31}$ values in the Padul-15-05 record between $\sim 30$ and $15.5 \mathrm{ka}$ BP (even after removing the ice volume effect) are not compatible with a predominant Atlantic precipitation source in southern Iberia during this period (Fig. 4). Reduced moisture advection from the north Atlantic under full glacial conditions (low sea surface temperatures) (Kaboth-Bahr et al., 2018; Tierney et al., 2020) and during other periods when the polar front shifted southward (Zanchetta et al., 2014) lowered Atlantic-derived precipitation in the study area. Conversely, our isotopic data agree with a western Mediterranean phase of enhanced net evaporation in sea surface water from $\sim 30$ to 20 ka BP (Toucanne et al., 2012). Therefore, we interpret long-term trends of low precipitation (low $\mathrm{P}_{\text {index }}$ and $\delta \mathrm{D}_{\mathrm{C} 31}$ enrichment) and some moisture contribution (isotopically-enriched) from the Mediterranean area for this period.

The period from $\sim 15.5$ to $\sim 5 \mathrm{ka} \mathrm{BP}$, here defined as the "Western Mediterranean Humid Period" (WMHP), represents the wettest stage in the last $\sim 35 \mathrm{ka}$. This period registers a notable increase in the $\mathrm{P}_{\text {index }}$ and a general depletion in the $\delta \mathrm{D}_{\mathrm{C} 31}$ values from Padul-15-05 (Figs. 3,4 ). It has been interpreted as a stage of enhanced winter precipitation in the whole Mediterranean region (Bosmans et al., 2015; Kutzbach et al., 2014; Wagner et al., 2019; Zielhofer et al., 2017), characterized by high orbitally-forced seasonality (Kutzbach et al., 2014). In the central and eastern Mediterranean this enhanced winter precipitation would have been caused by local Mediterranean cyclogenesis or convective events along with a southward shift of north Atlantic storm tracks (Bosmans et al., 2015; Wagner et al., 2019). In the westernmost areas of the Mediterranean this winter precipitation increase should be mainly related to Atlantic-sourced precipitation, as indicated by the general depletion in the $\delta \mathrm{D}_{\mathrm{C} 31}$ values in the Padul-15-05 record. This general western Mediterranean climatic trend agrees, for example, with the Younger Dryas (YD)-middle Holocene paleoenvironmental results deduced from ostracod oxygen isotopes from Lake Sidi Ali in the Moroccan Middle Atlas (Zielhofer et al., 2017).

Our data suggest a significant influence of Mediterranean precipitation (decreasing precipitation amount $-\mathrm{P}_{\text {index }}{ }^{-}$and gradual isotopically-enriched values) during the middle-late Holocene (from $\sim 5$ ka BP to the present), in agreement with previous isotopic studies in southern Iberia (e.g.,Toney et al., (2020) (Fig. 3c,g,h), and Morocco (Zielhofer et al., 2017). For this period, it could be the result of the prevailing NAO positive conditions during the last 5 ka (Atlantic westerly blocking) (Olsen et al., 2012; Zielhofer et al., 2017) associated with the general decreasing trend of north Atlantic sea surface temperatures (SST) after $\sim 5.5-5$ ka BP that would have shifted the storm track to a more northerly position (Collins et al., 2017), reducing the importance of the north Atlantic moisture source in the western Mediterranean. This prevalent blocking/shifting mechanism on the north Atlantic storm tracks would have been interrupted during important NAO negative

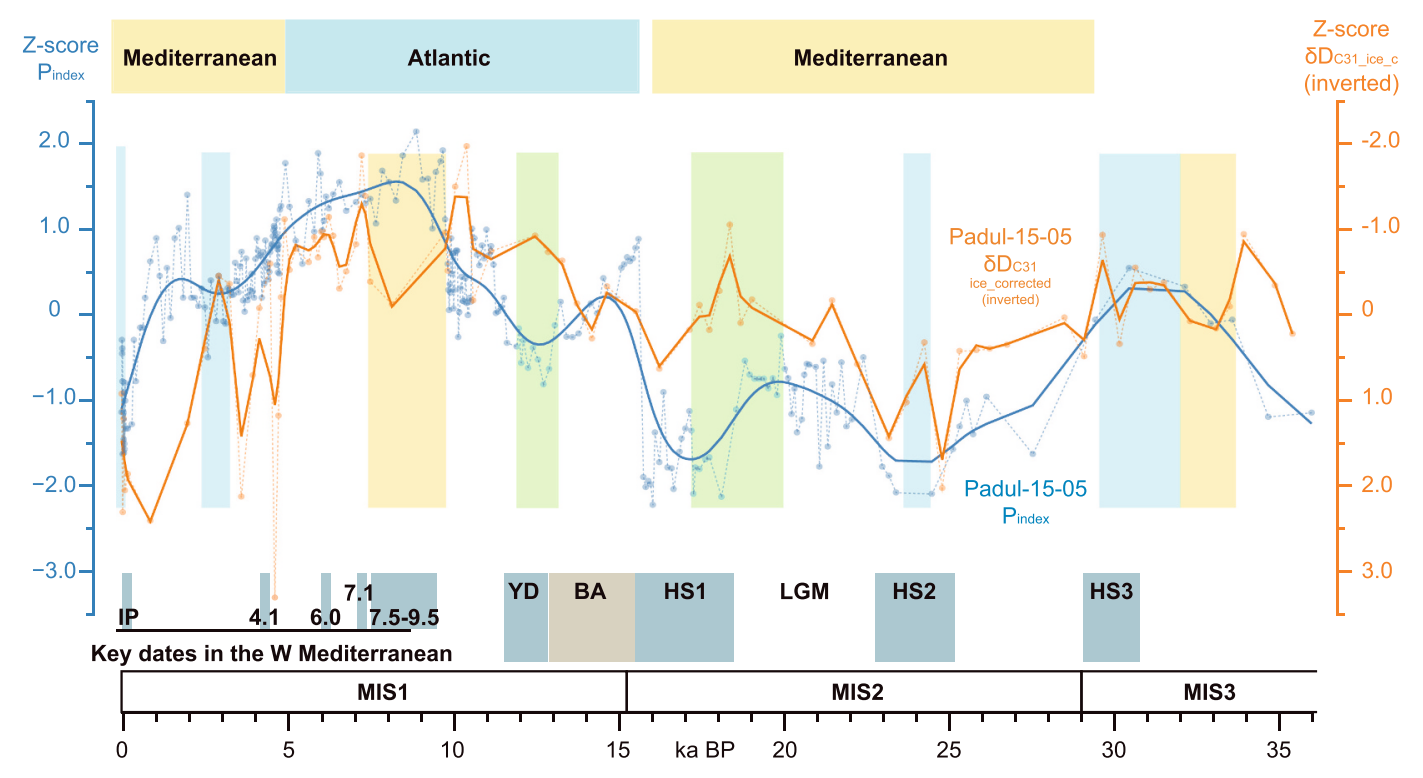

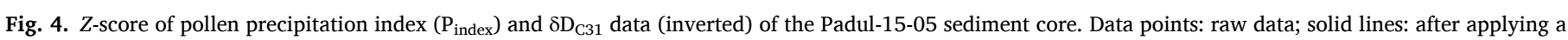

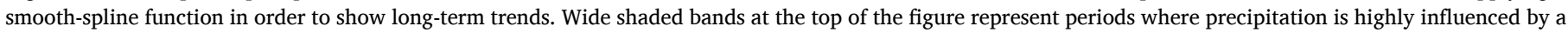

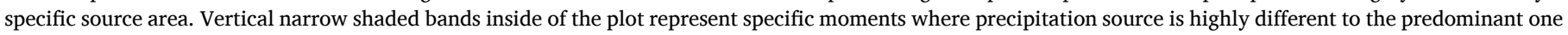

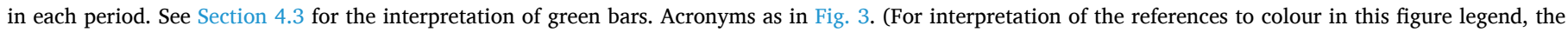
reader is referred to the web version of this article.) 
phases such as between $\sim 3-2 \mathrm{ka} \mathrm{BP}$ and during the Little Ice Age (Olsen et al., 2012) that could have enhanced Atlantic winter precipitation in southern Iberia derived from the occurrence of more north Atlantic storms entering the Mediterranean, according to the Padul-15-05 $\delta D_{\mathrm{C} 31}$ record (Figs. 3, 4).

Other western Mediterranean records from speleothems and lakes (e. g., Iberian Peninsula and Morocco) also show prevailing enriched isotopic values during glacial times that contrast with those of the early Holocene (Moreno et al., 2010; Roberts et al., 2008; Zielhofer et al., 2017; Toney et al., 2020, depicting an opposite pattern to northern and central European records (Roberts et al., 2008). These isotopic shifts were previously interpreted as changes in the moisture source and/or rainfall seasonality, apart from the potential influence of the amount of precipitation (Moreno et al., 2010; Roberts et al., 2008; Zielhofer et al., 2017). In this line of interpretation, Zielhofer et al. (2017) also proposed a shift throughout the Holocene from winter (Atlantic-sourced) to spring (Mediterranean-sourced) precipitation forced by the decrease of Atlantic storms in the western Mediterranean and changes in regional convection activity that would also agree with the southern Iberian $\delta D_{\text {wax }}$ records of LdRS Toney et al., 2020) and Padul 15-05 (this study).

\subsection{Potential drivers of millennial-scale paleohydrological changes}

When higher frequency, i.e., millennial-scale, changes are investigated, some periods do not follow the general anticorrelation observed between precipitation ( $\mathrm{P}_{\text {index }}$ ) and $\delta \mathrm{D}_{\mathrm{C} 31}$ trends in Padul 15-05 record. These include the periods $\sim 34-33,25-23,20-16,14-7.5 \mathrm{ka} \mathrm{BP}$, and the last $\sim 3.2 \mathrm{ka} \mathrm{BP}$ (Fig. 4). Interestingly, among these periods some showed an increase in precipitation and an enrichment in the hydrogen isotopes, e.g., from $\sim 9.5$ to $7.5 \mathrm{ka} \mathrm{BP}$ and from $\sim 2.4$ to $1 \mathrm{ka} \mathrm{BP}$. In other cases, the magnitude of the isotopic enrichment is much larger than the precipitation decrease such as from 5 to $3 \mathrm{ka}$ BP (Fig. 4). These occasional enrichments coeval with increasing precipitation would point towards a significant contribution of precipitation from the Mediterranean during these specific periods and/or an occasional reduction in the Atlantic moisture transport. Conversely, periods with depleted $\delta \mathrm{D}_{\mathrm{C} 31}$ values and low precipitation patterns such as from $\sim 25$ to 23 , from $\sim 20$ to 16 , from $\sim 13$ to 12 , from $\sim 3.2$ to $2.4 \mathrm{ka} \mathrm{BP}$, and the last $\sim 50$ years (Fig. 4 ) could probably be related to short episodes of enhanced contribution of an Atlantic moisture source, independently of the general atmospheric dynamic (Mediterranean or Atlantic) driving long-term phases. Nevertheless, due to the low sample resolution of some of these periods, we only focus on the HS1, the Younger Dryas (YD), and the early-middle Holocene transition (Fig. 4).

The interval from $\sim 20$ to $17 \mathrm{ka} \mathrm{BP}$, included in a period of prevailing Mediterranean precipitation, deserves special comment. $\mathrm{P}_{\text {index }}$ and $\delta \mathrm{D}_{\mathrm{C} 31}$ trends diverge showing a precipitation decrease coeval with an isotopic depletion (Fig. 4: green bar). In this period, the effect of cold icesheet and iceberg meltwater starting at $\sim 20$ ka BP (Sierro et al., 2005, 2020; Toucanne et al., 2009) along with the subsequent Atlantic Meridional Overturning Circulation (AMOC) slowdown (McManus et al., 2004) would deplete the isotopic signal of the precipitation generated from an Atlantic moisture source (freshwater inputs) and reduce the Atlantic moisture transport towards the Iberian Peninsula (decreased advection under lower sea surface temperatures (Tierney et al., 2020). Besides, a depletion in the isotopic composition of Mediterranean sea waters and colder SST are also expected due to the effect of both 1) an important amount of isotopically-depleted cold north Atlantic water entering the Mediterranean (Sierro et al., 2005, 2020), and to a lesser extent 2) the meltwater released from the Mediterranean glaciers in the Alps and Apennines (Bonneau et al., 2014). Under this scenario of cold Mediterranean and Atlantic waters the moisture advection, and thus precipitation, was low (low $\mathrm{P}_{\text {index }}$ ) and the main precipitation source in southeastern Iberia could have been either Atlantic or Mediterranean isotopically-depleted moisture, especially from 20 to $17.5 \mathrm{ka}$ $\mathrm{BP}$ and peaking at $18 \mathrm{ka}$ BP. Nevertheless, the large isotopic depletion between these specific dates would point towards an Atlantic influence. A similar precipitation scenario can be expected for the YD (Fig. 4: green bar), since it replicated (with less intensity) many features of the HS1 (Denton et al., 2010). However, in this case the abrupt depletion in the $\delta D_{\mathrm{C} 31}$ record is registered during a wetter period than the HS1 (Camuera et al., 2018, 2019; this study) and under a prevailing Atlantic moisture source (overall $\delta \mathrm{D}_{\mathrm{C} 31}$ depletion trend from $\sim 15.5$ to $5 \mathrm{ka} \mathrm{BP}$ ). Considering this last fact, YD precipitation would have been mainly affected by an even more depleted Atlantic precipitation source resulting from the ice-sheet meltwater release in the North Atlantic Ocean. Similar paleohydrological YD trends (dry climate and isotopically-depleted precipitation) have been observed in central and western Europe (Rach et al., 2014; Renssen et al., 2018).

Only a short phase of enhanced Mediterranean precipitation (high $\delta \mathrm{D}_{\mathrm{C} 31}$ values) is recorded during the Western Mediterranean Humid Period ( 15.5-5 ka BP), between $\sim 9.5$ and $7.5 \mathrm{ka}$ BP. This phase is coeval with a short north Atlantic cooling (Fletcher et al., 2012; Marcott et al., 2013), and thus, with a northward displacement of the north Atlantic westerlies (less winter storm tracks into the Mediterranean region) (Fletcher et al., 2012). In addition, a major re-organization of the Mediterranean circulation forced the slowdown of the Mediterranean thermohaline circulation between 9.5 and 7.5 (Göktürk et al., 2011; Jiménez-Espejo et al., 2007; Pérez-Asensio et al., 2020) that would have promoted lower Atlantic inputs into the Mediterranean basin and higher temperatures in the western Mediterranean (Ausín et al., 2015). This configuration could have boosted sea surface evaporation in this region, increasing Mediterranean sourced precipitation in southern Iberia at this specific period.

\subsection{Long-term synchronicity between western Mediterranean precipitation and western African Monsoon}

This study shows that north African and south Iberian records share similarities in their past hydrological patterns throughout the last glacial/interglacial transition and the Holocene, which is supported by previous studies Toney et al., 2020; Garcia-Alix et al., 2017; JiménezEspejo et al., 2014; Roberts et al., 2008), including long-term isotopic trends in precipitation (Jasechko et al., 2015).

In general terms, the isotopic composition of precipitation at low latitudes, and thus, the hydrogen isotopic signal that plants register (Niedermeyer et al., 2016), mainly depends on the amount of rainfall (Dansgaard, 1964). The correlation between the $\delta \mathrm{D}_{\mathrm{C} 31 \text { ice-c }}$ record from a sedimentary core at $\sim 15^{\circ} \mathrm{N}$ (GeoB9508-5) covering the last $\sim 44 \mathrm{ka}$ BP in the continental slope off Senegal (Niedermeyer et al., 2010) and the Padul-15-05 $\delta \mathrm{D}_{\mathrm{C} 31 \text { _ice-c }}$ record is high and statistically significant $(r$ $\geq 0.46 p<0.0001$ for raw data; $r>0.56 p<0.0001$ for a 5 -point moving average showing long-term trends) (Figs. $3 \mathrm{f}, \mathrm{h}$ and 5 ). The same can be applied to the correlation between the GeoB9508-5 $\delta \mathrm{D}_{\mathrm{C} 31 \text { ice-c }}$ record and the precipitation amount deduced from the Padul-15-05 pollen precipitation index $(r \leq-0.49 p<0.0001$ for raw data; $r<-0.67 p<$ 0.0001 for a 5 -point moving average showing long-term trends) (Fig. $3 c$, f). These observations support the similarities between the past hydrological oscillations of the western Mediterranean and northwestern Africa showing a major long-term parallel behavior of these regional systems: western Mediterranean winter precipitation and western African summer monsoon.

Overall, four main phases of long-term parallel precipitation patterns are observed in both southern Iberia and northwestern Africa sites: moderate-high and isotopically depleted precipitation occurred from $\sim 34$ to 29 ka BP (end of MIS 3), followed by low and isotopically enriched precipitation during MIS2, a precipitation increase associated with isotopic depletion from $\sim 15.5$ to $5 \mathrm{ka} \mathrm{BP}$, and a precipitation decrease and isotopic enrichment throughout the late Holocene (Fig. 5). The studied palaeohydrological proxies $\left(\delta \mathrm{D}_{\mathrm{C} 31}\right.$ and $\left.\mathrm{P}_{\text {index }}\right)$ show a good correlation with insolation changes in both systems (Fig. 3a,c,f,h), registering enhanced precipitation during periods of high seasonality (e. 


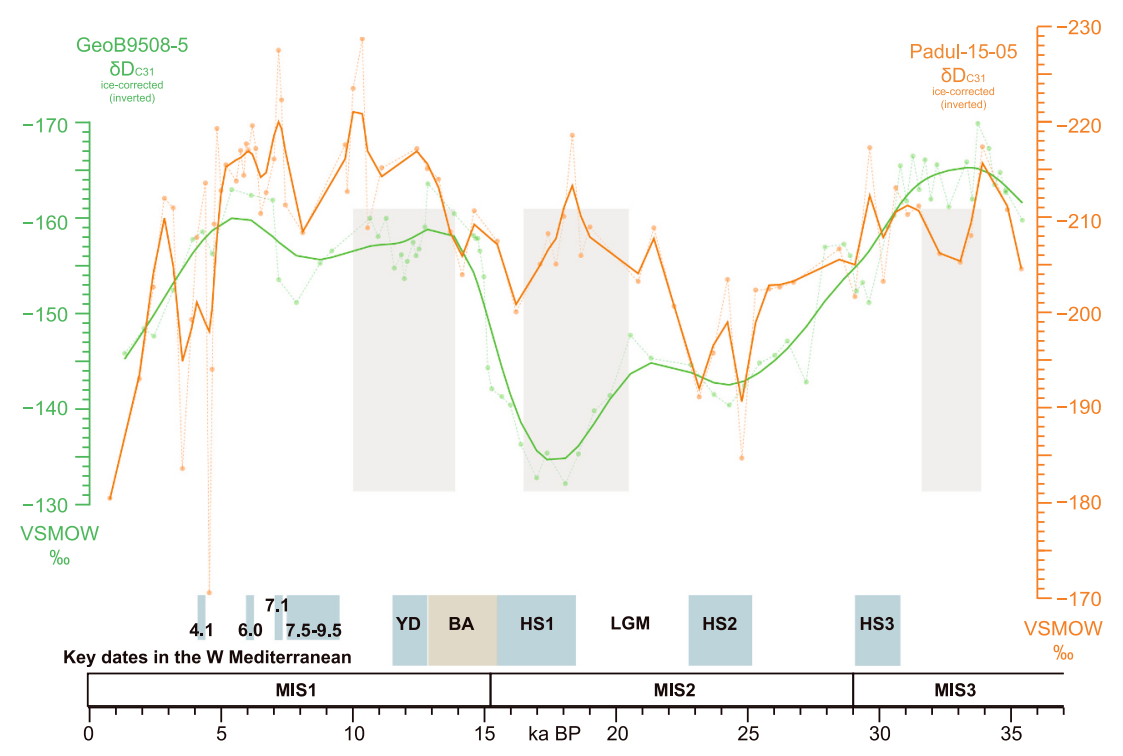

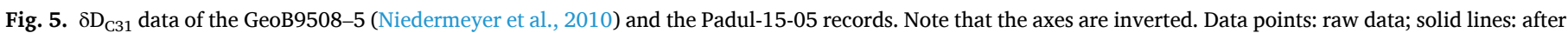
applying a smooth-spline function in order to show long-term trends. The grey shaded areas show periods where trends are opposite. Acronyms as in Fig. 3.

g., minimum precession and/or maximum obliquity) (Bosmans et al., 2015; Kutzbach et al., 2014; Wagner et al., 2019), and lower precipitation during periods of low seasonality. Long-term Northern Hemisphere summer insolation fluctuations have a primary control on the western African monsoon, showing a strong coupling with north Atlantic climate dynamics (McManus et al., 2004; Niedermeyer et al., 2010; Shanahan et al., 2015) that also regulate winter precipitation in the Mediterranean region (Bosmans et al., 2015; Kutzbach et al., 2014; Wagner et al., 2019). Long-term insolation fluctuations affect the SST and ocean circulation in the north Atlantic and thus, the long-term AMOC variability (Ayache et al., 2018; Otto-Bliesner et al., 2014; McManus et al., 2004) that modifies the moisture delivery (Atlantic storm tracks) in the western Mediterranean through fluctuation of the Atlantic Westerly Jet (Smith et al., 2016), and modulates the position of the ITCZ over the Atlantic Ocean and hence, the western African summer monsoon (Otto-Bliesner et al., 2014; Marshall et al., 2014).

Most of the studies comparing monsoonal and Mediterranean precipitation dynamics have paid little attention to the potential parallel responses of these two systems during periods of low seasonality with maximum precession and/or minimum obliquity (e.g., MIS2). This paleohydrological synchronism is observed between both Padul-15-05 ( $\mathrm{P}_{\text {index }}$ and $\left.\delta \mathrm{D}_{\mathrm{C} 31}\right)$ and GeoB9508-5 ( $\left.\delta \mathrm{D}_{\mathrm{C} 31}\right)$ records (Figs. 3a,c,f,h and 5). In these periods, Northern Hemisphere orbitally-forced dynamics, such as the ice sheet expansion and AMOC fluctuations, triggered 1) the general southward displacement of the ITCZ giving rise to enhanced arid and cold conditions in northwestern Africa (less tropical moisture advection) (Chiang and Bitz, 2005; Denton et al., 2010; McManus et al., 2004) and 2) the overall decrease or northward shift of Atlantic storms (Li and Battisti, 2008) that reduced precipitation in the western Mediterranean.

Apart from the long-term similarities between both regions, clear shorter millennial-scale periods with different precipitation trends are observed (Fig. 5) such as from $\sim 34$ to 31.5 , from $\sim 20.5$ to 16 (especially during the HS1), and from $\sim 14$ to $10 \mathrm{ka}$ BP (especially during the YD) (Fig. 5). The latter two cases agree with the last glacial-interglacial transition under a scenario of increasing summer insolation in the Northern Hemisphere (Laskar et al., 2004). During these periods $\delta D_{C 31}$ values of the Padul area depicted an isotopic depletion trend with no evident increase in precipitation (low $\mathrm{P}_{\text {index }}$ ) (Fig. 4), likely caused by isotopically-depleted Atlantic (and/or Mediterranean) sources after massive ice meting (see Section 4.3), whereas the northwestern African $\delta \mathrm{D}_{\mathrm{C} 31}$ record showed an isotopic enrichment, consistent with dry conditions (Fig. 5). Important droughts during the HS1 and YD in western Africa related to the weakening of the west African monsoon might be a consequence of these cold north Atlantic meltwater releases that started at $\sim 20$ ka BP (Toucanne et al., 2009) that were especially intense during the HS1 and YD (Denton et al., 2010), causing the collapse/slowdown of the AMOC (McManus et al., 2004) and the subsequent southwards migration of the Intertropical Convergence Zone (ITCZ) (Denton et al., 2010; Shanahan et al., 2015). HS1 and YD arid stages did not seem to be so climatically extreme in southern Iberia, as can be observed in the Padul-15-05 record (Figs. 3 and 5) and other studies (Naughton et al., 2016; Salgueiro et al., 2014; Voelker et al., 2009).

Although the wettest stages in both areas during the AHP and WMHP are coeval (from $\sim 11.5$ to $5 \mathrm{ka}$ ), the timing of the maximum precipitation is asynchronous. The highest precipitation $\left(\mathrm{P}_{\text {index }}\right)$ values in southern Iberian are recorded from $\sim 10.5$ to $7 \mathrm{ka} \mathrm{BP}$ peaking at $\sim 9 \mathrm{ka}$ $\mathrm{BP}$, agreeing with the highest $\delta \mathrm{D}_{\mathrm{C} 31}$ depletion (at $\sim 10$ and $7 \mathrm{ka} \mathrm{BP}$ ) (Figs. 3c,h and 4). However, the highest $\delta \mathrm{D}_{\mathrm{C} 31}$ depletion in northwestern Africa is registered from $\sim 7$ to $4.8 \mathrm{ka} \mathrm{BP}$, peaking at $\sim 6-5.5 \mathrm{ka} \mathrm{BP}$ (Niedermeyer et al., 2010) (Figs. 3f and 5). This lack of synchronicity in maximum precipitation between both records along with the generally more depleted isotopic leaf wax pattern in southern Iberia (ranging from -228 to $-207 \%$ ) from $\sim 11$ to 6 ka BP (Fig. 5) rules out a significant monsoonal moisture recycling from northwestern Africa during the African Humid Period as potential source of humidity in the western Mediterranean area. This fact would support a proper Western Mediterranean Humid Period independent from the African Humid Period.

Precipitation decreased during the (middle)-late Holocene in the western Mediterranean and western Africa. The demise of the AHP was inferred to be forced by both decreasing north Atlantic SST after $\sim 5.5-5$ ka BP (Collins et al., 2017) and an AMOC weakening (Ayache et al., 2018), ultimately controlled by an insolation decrease, along with regional biogeophysical feedbacks (Ayache et al., 2018; Collins et al., 2017). These forcing mechanism had an effect on north African moisture through the reduction of the Tropical Easterly Jet and the enhancement of the African Easterly Jet (Fig. 1a) (Collins et al., 2017). Similarly, the end of the WMHP likely was triggered by these north Atlantic changes that reduced the north Atlantic moisture advection into the western Mediterranean along with a northward storm track shift as a consequence of prevailing NAO positive conditions during the last $5 \mathrm{ka}$ (Olsen et al., 2012) and/or decreasing north Atlantic SST after $\sim 5.5-5$ ka BP 
(Collins et al., 2017).

\section{Conclusions}

This paper uses leaf wax hydrogen isotopic ratios and a pollenderived precipitation proxy $\left(\mathrm{P}_{\text {index }}\right)$ from a sedimentary core at the Padul wetland to reconstruct paleohydrological changes during the last $\sim 35 \mathrm{ka}$ in the western Mediterranean. Additionally, the comparison between the studied southern Iberian core and a low latitude monsoonal record shows significant similarities during the last $\sim 35 \mathrm{ka}$.

Modern precipitation isotopes, airmass backtrajectories, and previously published data allowed the identification of the varying influence of two main precipitation sources with different isotopic signatures in the study area. An Atlantic source predominates during the cold season and gives rise to far more abundant and isotopically depleted rainfall compared to a Mediterranean source, which is primarily registered during the warm season. Our results suggest that the hydrogen isotope composition of leaf waxes does not allow the separation of amount and source of precipitation in the Padul-15-05 record. Nevertheless, its combination with the pollen precipitation index $\left(\mathrm{P}_{\text {index }}\right)$ can be used to successfully track the join evolution of the amount and source of precipitation in the westernmost Mediterranean region. This is especially interesting in short phases when both proxies exhibited a diverging behavior. Other potential controls that could have affected the hydrogen isotope composition of leaf waxes such as temperature or evapotranspiration were either negligible at the studied long-term time-scale or overprinted by these two main drivers.

During the last $\sim 35$ ka we identify wetter and drier periods with different rainfall contribution from one or the other moisture source: from $\sim 30$ to $15.5 \mathrm{ka} \mathrm{BP}$ and from $\sim 5 \mathrm{ka}$ BP to the present overall low precipitation with enriched isotopic values points towards important inputs from a Mediterranean precipitation source (and/or a reduction of Atlantic moisture transport). The interval from $\sim 15.5$ to $5 \mathrm{ka} B P$ on the other hand showed a notable precipitation increase with a primary Atlantic origin (winter precipitation). This latter period is here defined as the Western Mediterranean Humid Period, which is coeval with the African Humid Period. Some millennial-scale events of enhanced contribution from an Atlantic (Mediterranean) moisture source, can be also occurred in a period with opposite general Mediterranean (Atlantic) pattern (e.g. HS1, early-middle Holocene). Considering that the Iberian Peninsula is on the trajectory of the Atlantic storm tracks over the Mediterranean Basin, the most parsimonious explanation for these fluctuations of precipitation amount and source would point to periods with different behavior of the Atlantic storm tracks. Periods of low precipitation in the Iberian Peninsula, which are usually associated with blocked or displaced Atlantic storm tracks, reflect a higher contribution of Mediterranean isotopically-enriched water vapor to the weighted precipitation amount.

The comparison between the studied southern Iberian and low latitude monsoonal records exhibits several similarities showing increasing north Atlantic influence on atmospheric dynamics after $\sim 15.5 \mathrm{ka}$ BP. This north Atlantic influence decreased in the middle Holocene, leading to the end of the AHP and the WMHP and the establishment of a new mode of atmospheric dynamic at around 5 ka BP. These paleohydrological similarities in the western Mediterranean and northwestern Africa during the last $\sim 35 \mathrm{ka}$ suggest paired responses to the forcing mechanisms controlling the moisture delivery in the Northern Hemisphere, such us north Atlantic temperatures and the AMOC, that ultimately depend on orbitally-forced northern Hemisphere climate dynamics. Nevertheless, there are some occasional (millennial-scale) periods of disagreement between both western Mediterranean and northwestern Africa isotopic records, such as the HS1 and the YD. During these intervals the effect of freshwater release after massive ice melting, lowering north Atlantic and Mediterranean isotopic signals, prevailed over the precipitation amount and source effect on the $\delta D_{C 31}$ record of southern Iberia, mirroring the trend of other European records at higher latitudes.

\section{Declaration of Competing Interest}

None.

\section{Acknowledgements}

This study was supported by the project B-RNM-144-UGR18 of the action "Proyectos I+D+i del Programa Operativo FEDER 2018 - Junta de Andalucía-UGR", the projects CGL2013-47038-R and CGL201785415-R, of the "Ministerio de Economía y Competitividad of Spain and Fondo Europeo de Desarrollo Regional FEDER", and the research group RNM-190 (Junta de Andalucía). A.G.-A. was also supported by a Marie Curie Intra-European Fellowship of the 7th Framework Programme for Research, Technological Development and Demonstration of the vEuropean Commission (NAOSIPUK. Grant Number: PIEF-GA-2012-623027) and by a Ramón y Cajal Fellowship RYC-2015-18966 of the Spanish Government (Ministerio de Economía y Competividad). J.C. acknowledges the postdoctoral funding provided by the Academy of Finland (project number 316702). J.L.T. hosted the NAOSIPUK project (PIEFGA-2012-623027) at the University of Glasgow. A.L.-A PhD is funded by BES-2018-084293 (Ministerio de Economía y Competividad). M.J.R.R. acknowledges the postdoctoral funding by the European Research Council (ERC-2017-ADG-788616). This study was supported by an ERC Consolidator Grant (STEEPclim) to D.S. (Grant Agreement No. 647035). E.S. is supported by the DFG Cluster of Excellence 2077 >The Ocean Floor - Earth's Uncharted Interface〈 at MARUM. We thank Ralph Kreutz for analytical support.

\section{Appendix A. Supplementary data}

Supplementary data to this article can be found online at https://doi. org/10.1016/j.gloplacha.2021.103527.

\section{References}

Álvarez-Lao, D., Kahlke, R.D., García, N., Mol, D., 2009. The Padul mammoth finds - on the southernmost record of Mammuthus primigenius in Europe and its southern spread during the late Pleistocene. Palaeogeogr. Palaeoclimatol. Palaeoecol. 278, $57-70$.

Andersen, K.K., Azuma, N., Barnola, J.M., Bigler, M., Biscaye, P., Caillon, N., Chappellaz, J., Clausen, H.B., Dahl-Jensen, D., Fischer, H., Flückiger, J., Fritzsche, D., Fujii, Y., Goto-Azuma, K., Grønvold, K., Gundestrup, N.S., Hansson, M., Huber, C., Hvidberg, C.S., Johnsen, S.J., Jonsell, U., Jouzel, J., Kipfstuhl, S., Landais, A., Leuenberger, M., Lorrain, R., Masson-Delmotte, V., Miller, H., Motoyama, H., Narita, H., Popp, T., Rasmussen, S.O., Raynaud, D., Rothlisberger, R., Ruth, U., Samyn, D., Schwander, J., Shoji, H., Siggard-Andersen, M.L., Steffensen, J. P., Stocker, T., Sveinbjörnsdóttir, A.E., Svensson, A., Takata, M., Tison, J.L., Thorsteinsson, T., Watanabe, O., Wilhelms, F., White, J.W.C., North Greenland Ice Core Project, m, 2004. High-resolution record of Northern Hemisphere climate extending into the last interglacial period. Nature 431, 147-151.

Anderson, R.S., Jiménez-Moreno, G., Carrión, J., Pérez-Martinez, C., 2011. Postglacial history of alpine vegetation, fire, and climate from Laguna de Río Seco, Sierra Nevada, southern Spain. Quat. Sci. Rev. 30, 1615-1629.

Araguas-Araguas, L.J., Diaz Teijeiro, M.F., 2005. Isotope composition of precipitation and water vapour in the Iberian Peninsula. In: First results of the Spanish Network of Isotopes in Precipitation, Isotopic composition of precipitation in the Mediterranean Basin in relation to air circulation patterns and climate. IAEA-TECDOC-1453, Vienna, pp. 173-190.

Ausín, B., Flores, J.A., Sierro, F.J., Cacho, I., Hernández-Almeida, I., Martrat, B. Grimalt, J.O., 2015. Atmospheric patterns driving Holocene productivity in the Alboran Sea (Western Mediterranean): A multiproxy approach. The Holocene 25, 583-595.

Ayache, M., Swingedouw, D., Mary, Y., Eynaud, F., Colin, C., 2018. Multi-centennial variability of the AMOC over the Holocene: A new reconstruction based on multiple proxy-derived SST records. Glob. Planet. Chang. 170, 172-189.

Bonneau, L., Jorry, S.J., Toucanne, S., Jacinto, R.S., Emmanuel, L., 2014. Millennial-scale response of a western mediterranean river to late quaternary climate changes: a view from the Deep Sea. J. Geol. 122, 687-703.

Bosmans, J.H.C., Drijfhout, S.S., Tuenter, E., Hilgen, F.J., Lourens, L.J., Rohling, E.J., 2015. Precession and obliquity forcing of the freshwater budget over the Mediterranean. Quat. Sci. Rev. 123, 16-30.

Bowen, G.J., 2020. The Online Isotopes in Precipitation Calculator, version 3.1. http://www.waterisotopes.org. 
Pérez Latorre, A.V., Cabezudo, B., 2002. Use of monocharacteristic growth forms and phenological phases to describe and differentiate plant communities in Mediterranean-type ecosystems. Plant Ecol. 161, 231-249.

Camuera, J., Ramos Román, M.J., Jiménez Moreno, G., López Sáez, J.A., Alba Sánchez, F., 2017. El Padul, un enclave natural y un registro sedimentario excepcionales. Sus humedales y turberas. Revista PH-Instituto Andaluz del Patrimonio Histórico 91, 72-80.

Camuera, J., Jiménez-Moreno, G., Ramos-Román, M.J., García-Alix, A., Toney, J.L., Anderson, R.S., Jiménez-Espejo, F., Kaufman, D., Bright, J., Webster, C., Yanes, Y. Carrión, J.S., Ohkouchi, N., Suga, H., Yamame, M., Yokoyama, Y., Martínez-Ruiz, F., 2018. Orbital-scale environmental and climatic changes recorded in a new 200,000-year-long multiproxy sedimentary record from Padul, southern Iberian Peninsula. Quat. Sci. Rev. 198, 91-114.

Camuera, J., Jiménez-Moreno, G., Ramos-Román, M.J., García-Alix, A., Toney, J.L., Anderson, R.S., Jiménez-Espejo, F., Bright, J., Webster, C., Yanes, Y., Carrión, J.S. 2019. Vegetation and climate changes during the last two glacial-interglacial cycles in the western Mediterranean: A new long pollen record from Padul (southern Iberian Peninsula). Quat. Sci. Rev. 205, 86-105.

Celle-Jeanton, H., Travi, Y., Blavoux, B., 2001. Isotopic typology of the precipitation in the Western Mediterranean Region at three different time scales. Geophys. Res. Lett. $28,1215-1218$.

Chiang, J.C.H., Bitz, C.M., 2005. Influence of high latitude ice cover on the marine Intertropical Convergence Zone. Clim. Dyn. 25, 477-496.

Collins, J.A., Prange, M., Caley, T., Gimeno, L., Beckmann, B., Mulitza, S., Skonieczny, C., Roche, D., Schefuß, E., 2017. Rapid termination of the African Humid Period triggered by northern high-latitude cooling. Nat. Commun. 8, 1372.

Cruz Blanco, M., 2014. New Techniques for Determining Reference Evapotranspiration de Referencia. Servicio de Publicaciones de la Universidad de Córdoba.

D'Agostino, R., Lionello, P., 2020. The atmospheric moisture budget in the Mediterranean: Mechanisms for seasonal changes in the last Glacial Maximum and future warming scenario. Quat. Sci. Rev. 241, 106392.

Dansgaard, W., 1964. Stable isotopes in precipitation. Tellus 16, 436-468.

Denton, G.H., Anderson, R.F., Toggweiler, J.R., Edwards, R.L., Schaefer, J.M., Putnam, A. E., 2010. The last Glacial termination. Science 328, 1652-1656.

Domínguez-Villar, D., Carrasco, R.M., Pedraza, J., Cheng, H., Edwards, R.L., Willenbring, J.K., 2013. Early maximum extent of paleoglaciers from Mediterranean mountains during the last glaciation. Sci. Rep. 3, 2034.

Dong, L., Leung, L.R., Lu, J., Song, F., 2021. Double-ITCZ as an emergent constraint for future precipitation over mediterranean climate regions in the North Hemisphere. Geophys. Res. Lett. 48, e2020GL091569.

Esteban-Parra, M.J., Rodrigo, F.S., Castro-Diez, Y., 1998. Spatial and temporal patterns of precipitation in Spain for the period 1880-1992. Int. J. Climatol. 18, 1557-1574.

Feakins, S.J., Sessions, A.L., 2010. Controls on the D/H ratios of plant leaf waxes in an arid ecosystem. Geochim. Cosmochim. Acta 74, 2128-2141.

Fontboté, J.M., Gallegos, J.A., González Donoso, J.M., Sanz de Galdeano, C., 1980. Mapa geológico de Padul. IGME.

Fletcher, W.J., Goni, M.F.S., Peyron, O., Dormoy, I., 2010. Abrupt climate changes of the last deglaciation detected in a Western Mediterranean forest record. Clim. Past 6, 245-264.

Fletcher, W.J., Debret, M., Goñi, M.F.S., 2012. Mid-Holocene emergence of a lowfrequency millennial oscillation in western Mediterranean climate: Implications for past dynamics of the North Atlantic atmospheric westerlies. The Holocene 23, $153-166$.

García-Alix, A., 2015. A multiproxy approach for the reconstruction of ancient continental environments. The case of the Mio-Pliocene deposits of the Granada Basin (southern Iberian Peninsula). Glob. Planet. Chang. 131, 1-10.

García-Alix, A., Minwer-Barakat, R., Martín, J.M., Martín Suárez, E., Freudenthal, M., Garca-Alix, A., Minwer-Barakat, R., Martn, J.M., Surez, E.M., Freudenthal, M., 2009. Dating the change from endorheic to exorheic conditions in the drainage system of the Granada Basin (Southern Spain). Palaios 24, 544-549.

García-Alix, A., Delgado Huertas, A., Martín Suárez, E., 2012. Unravelling the late Pleistocene habitat of the southernmost woolly mammoths in Europe. Quat. Sci. Rev. $32,75-85$.

Garcia-Alix, A., Jimenez Espejo, F.J., Toney, J.L., Jiménez-Moreno, G., RamosRomán, M.J., Anderson, R.S., Ruano, P., Queralt, I., Delgado Huertas, A., Kuroda, J. 2017. Alpine bogs of southern Spain show human-induced environmental change superimposed on long-term natural variations. Sci. Rep. 7, 7439.

Gimeno, L., Nieto, R., Trigo, R.M., Vicente-Serrano, S.M., López-Moreno, J.I., 2010. Where does the Iberian Peninsula moisture come from? An Answer based on a Lagrangian approach. J. Hydrometeorol. 11, 421-436.

Giorgi, F., 2006. Climate change hot-spots. Geophys. Res. Lett. 33.

Göktürk, O.M., Fleitmann, D., Badertscher, S., Cheng, H., Edwards, R.L. Leuenberger, M., Fankhauser, A., Tüysüz, O., Kramers, J., 2011. Climate on the southern Black Sea coast during the Holocene: implications from the Sofular Cave record. Quat. Sci. Rev. 30, 2433-2445.

Gómez-Hernández, M., Drumond, A., Gimeno, L., Garcia-Herrera, R., 2013. Variability of moisture sources in the Mediterranean region during the period 1980-2000. Water Resour. Res. 49, 6781-6794.

Gonzalez-Hidalgo, J.C., Lopez-Bustins, J.-A., Štepánek, P., Martin-Vide, J., de Luis, M., 2009. Monthly precipitation trends on the Mediterranean fringe of the Iberian Peninsula during the second-half of the twentieth century (1951-2000). Int. J. Climatol. 29, 1415-1429.

Hammer, Ø., Harper, D.A.T., Ryan, P.D., 2001. PAST: Paleontological statistics software package for education and data analysis. Palaeontol. Electron. 4, 9.
Hughes, P.D., Gibbard, P.L., Ehlers, J., 2013. Timing of glaciation during the last glacial cycle: evaluating the concept of a global 'last Glacial Maximum' (LGM). Earth Sci. Rev. 125, 171-198.

IPCC, 2013. Climate Change 2013: The Physical Science Basis. Contribution of Working Group I to the Fifth Assessment Report of the Intergovernmental Panel on Climate Change. Cambridge University Press, Cambridge, United Kingdom and New York, USA.

IPCC, 2014. Climate Change 2014: Impacts, Adaptation, and Vulnerability. Part B: Regional Aspects. Contribution of Working Group II to the Fifth Assessment Report of the Intergovernmental Panel on Climate Change. Cambridge University Press, Cambridge, United Kingdom and New York, NY, USA.

ITGE-COPTJA, 1998. Atlas hidrogeológico de Andalucía. Andalucía, IGME-Junta de, p. 216.

Jasechko, S., Lechler, A., Pausata, F.S.R., Fawcett, P.J., Gleeson, T., Cendón, D.I., Galewsky, J., LeGrande, A.N., Risi, C., Sharp, Z.D., Welker, J.M., Werner, M., Yoshimura, K., 2015. Late-glacial to late-Holocene shifts in global precipitation $\delta^{18} \mathrm{O}$. Clim. Past 11, 1375-1393.

Jiménez-Moreno, G., Anderson, R.S., 2012. Holocene vegetation and climate change recorded in alpine bog sediments from the Borreguiles de la Virgen, Sierra Nevada, southern Spain. Quaternary Research 77, 44-53 https://doi.org/https://doi.org/ 10.1016/j.yqres.2011.09.006.

Jiménez-Espejo, F.J., Martínez-Ruiz, F, Finlayson, C, Paytan, A, Sakamoto, T, OrtegaHuertas, M, Finlayson, G, Iijima, K, Gallego-Torres, D, Fa, D, , et al.Martínez-Ruiz, F., Finlayson, C., Paytan, A., Sakamoto, T., Ortega-Huertas, M., Finlayson, G., Iijima, K., Gallego-Torres, D., Fa, D., 2007. Climate forcing and Neanderthal extinction in Southern Iberia: insights from a multiproxy marine record. Quat. Sci. Rev. 26, 836-852.

Jiménez-Espejo, F.J., García-Alix, A., Jiménez-Moreno, G., Rodrigo-Gámiz, M., Anderson, R.S., Rodríguez-Tovar, F.J., Martínez-Ruiz, F., Giralt, S., Delgado Huertas, A., Pardo-Igúzquiza, E., 2014. Saharan aeolian input and effective humidity variations over western Europe during the Holocene from a high altitude record. Chem. Geol. 374-375, 1-12.

Kaboth-Bahr, S., Bahr, A., Zeeden, C., Toucanne, S., Eynaud, F., Jiménez-Espejo, F., Röhl, U., Friedrich, O., Pross, J., Löwemark, L., Lourens, L.J., 2018. Monsoonal Forcing of European Ice-Sheet Dynamics during the late Quaternary. Geophys. Res. Lett. 45, 7066-7074.

Kohfahl, C., Sprenger, C., Herrera, J.B., Meyer, H., Chacón, F.F., Pekdeger, A., 2008. Recharge sources and hydrogeochemical evolution of groundwater in semiarid and karstic environments: A field study in the Granada Basin (Southern Spain). Appl. Geochem. 23, 846-862.

Krklec, K., Domínguez-Villar, D., 2014. Quantification of the impact of moisture source regions on the oxygen isotope composition of precipitation over Eagle Cave, Central Spain. Geochim. Cosmochim. Acta 134, 39-54.

Kutzbach, J.E., Chen, G., Cheng, H., Edwards, R.L., Liu, Z., 2014. Potential role of winter rainfall in explaining increased moisture in the Mediterranean and Middle East during periods of maximum orbitally-forced insolation seasonality. Clim. Dyn. 42, 1079-1095.

Laîné, A., Kageyama, M., Salas-Mélia, D., Voldoire, A., Rivière, G., Ramstein, G., Planton, S., Tyteca, S., Peterschmitt, J.Y., 2009. Northern hemisphere storm tracks during the last glacial maximum in the PMIP2 ocean-atmosphere coupled models: energetic study, seasonal cycle, precipitation. Clim. Dyn. 32, 593-614.

Laskar, J., Robutel, P., Joutel, F., Gastineau, M., Correia, A.C.M., Levrard, B., 2004. A long-term numerical solution for the insolation quantities of the Earth. Astron. Astrophys. 428, 261-285.

Li, C., Battisti, D.S., 2008. Reduced atlantic storminess during last glacial maximum: evidence from a coupled climate model. J. Clim. 21, 3561-3579.

Lionello, P., Malanotte-Rizzoli, P., Boscolo, R., Alpert, P., Artale, V., Li, L., Luterbacher, J., May, W., Trigo, R., Tsimplis, M., Ulbrich, U., Xoplaki, E., 2006. The Mediterranean climate: an overview of the main characteristics and issues. Dev. Earth Environ. Sci. 1-26.

Ludwig, P., Schaffernicht, E.J., Shao, Y., Pinto, J.G., 2016. Regional atmospheric circulation over Europe during the last Glacial Maximum and its links to precipitation. J. Geophys. Res.-Atmos. 121, 2130-2145.

Ludwig, P., Pinto, J.G., Raible, C.C., Shao, Y., 2017. Impacts of surface boundary conditions on regional climate model simulations of European climate during the last Glacial Maximum. Geophys. Res. Lett. 44, 5086-5095.

Ludwig, P., Shao, Y., Kehl, M., Weniger, G.-C., 2018. The last Glacial Maximum and Heinrich event I on the Iberian Peninsula: A regional climate modelling study for understanding human settlement patterns. Glob. Planet. Chang. 170, 34-47.

Luetscher, M., Boch, R., Sodemann, H., Spötl, C., Cheng, H., Edwards, R.L., Frisia, S., Hof, F., Müller, W., 2015. North Atlantic storm track changes during the last Glacial Maximum recorded by Alpine speleothems. Nat. Commun. 6, 6344.

Marcott, S.A., Shakun, J.D., Clark, P.U., Mix, A.C., 2013. A reconstruction of regional and global temperature for the past 11,300 years. Science 339, 1198-1201.

Marshall, J., Donohoe, A., Ferreira, D., McGee, D., 2014. The ocean's role in setting the mean position of the Inter-Tropical Convergence Zone. Clim. Dyn. 42, 1967-1979.

Martin-Vide, J., Lopez-Bustins, J.A., 2006. The Western Mediterranean Oscillation and rainfall in the Iberian Peninsula. Int. J. Climatol. 26, 1455-1475.

Martrat, B., Grimalt, J.O., Lopez-Martinez, C., Cacho, I., Sierro, F.J., Flores, J.A., Zahn, R., Canals, M., Curtis, J.H., Hodell, D.A., 2004. Abrupt temperature changes in the Western Mediterranean over the past 250,000 years. Science 306, 1762-1765.

McManus, J.F., Francois, R., Gherardi, J.M., Keigwin, L.D., Brown-Leger, S., 2004. Collapse and rapid resumption of Atlantic meridional circulation linked to deglacial climate changes. Nature 428, 834-837.

Menéndez-Amor, J., Florschütz, F., 1962. Un aspect de la végétation en Espagne méridionale durant la dernière glaciation et L'Holocène. Geol. Mijnb. 41, 131-134. 
Mix, A.C., Bard, E., Schneider, R., 2001. Environmental processes of the ice age: land, oceans, glaciers (EPILOG). Quat. Sci. Rev. 20, 627-657.

Moreno, A., Stoll, H., Jiménez-Sánchez, M., Cacho, I., Valero-Garcés, B., Ito, E., Edwards, R.L., 2010. A speleothem record of glacial (25-11.6kyr BP) rapid climatic changes from northern Iberian Peninsula. Glob. Planet. Chang. 71, 218-231.

Moreno, A., González-Sampériz, P., Morellón, M., Valero-Garcés, B.L., Fletcher, W.J., 2012. Northern Iberian abrupt climate change dynamics during the last glacial cycle: A view from lacustrine sediments. Quat. Sci. Rev. 36, 139-153.

Moreno, A., Sancho, C., Bartolomé, M., Oliva-Urcia, B., Delgado-Huertas, A., Estrela, M. J., Corell, D., López-Moreno, J.I., Cacho, I., 2014. Climate controls on rainfall isotopes and their effects on cave drip water and speleothem growth: the case of Molinos cave (Teruel, NE Spain). Clim. Dyn. 43, 221-241.

Naughton, F., Sanchez Goñi, M.F., Rodrigues, T., Salgueiro, E., Costas, S., Desprat, S., Duprat, J., Michel, E., Rossignol, L., Zaragosi, S., Voelker, A.H.L., Abrantes, F., 2016 Climate variability across the last deglaciation in NW Iberia and its margin. Quat. Int. 414, 9-22.

Niedermeyer, E.M., Schefuß, E., Sessions, A.L., Mulitza, S., Mollenhauer, G., Schulz, M., Wefer, G., 2010. Orbital- and millennial-scale changes in the hydrologic cycle and vegetation in the western African Sahel: insights from individual plant wax $\delta \mathrm{D}$ and $\delta^{13}$ C. Quat. Sci. Rev. 29, 2996-3005.

Niedermeyer, E.M., Forrest, M., Beckmann, B., Sessions, A.L., Mulch, A., Schefuß, E., 2016. The stable hydrogen isotopic composition of sedimentary plant waxes as quantitative proxy for rainfall in the West African Sahel. Geochim. Cosmochim. Acta 184, 55-70.

Oliva, M., Moreno, I., 2008. Sierra nevada, nexo entre dos patrones de teleconexión: la NAO y la WEMO, Cambio Climático Regional y sus Impactos. Publicaciones de la Asociación Española de Climatología 199-208.

Oliva, M., Palacios, D., Fernández-Fernández, J.M., Rodríguez-Rodríguez, L., GarcíaRuiz, J.M., Andrés, N., Carrasco, R.M., Pedraza, J., Pérez-Alberti, A., Valcárcel, M., Hughes, P.D., 2019. Late Quaternary glacial phases in the Iberian Peninsula. Earth Sci. Rev. 192, 564-600.

Olsen, J., Anderson, N.J., Knudsen, M.F., 2012. Variability of the North Atlantic Oscillation over the past 5,200 years. Nat. Geosci. 5, 808-812.

Ortiz, J.E., Torres, T., Delgado, A., Julià, R., Lucini, M., Llamas, F.J., Reyes, E., Soler, V., Valle, M., 2004. The palaeoenvironmental and palaeohydrological evolution of Padul Peat Bog (Granada, Spain) over one million years, from elemental, isotopic and molecular organic geochemical proxies. Org. Geochem. 35, 1243-1260.

Ortiz, J.E., Torres, T., Delgado, A., Llamas, J.F., Soler, V., Valle, M., Julià, R., Moreno, L., Díaz-Bautista, A., 2010. Palaeoenvironmental changes in the Padul Basin (Granada, Spain) over the last 1Ma based on the biomarker content. Palaeogeogr. Palaeoclimatol. Palaeoecol. 298, 286-299.

Otto-Bliesner, B.L., Russell, J.M., Clark, P.U., Liu, Z., Overpeck, J.T., Konecky, B., deMenocal, P., Nicholson, S.E., He, F., Lu, Z., 2014. Coherent changes of southeastern equatorial and northern African rainfall during the last deglaciation. Science 346, 1223-1227.

Palacios, D., Gómez-Ortiz, A., Andrés, N., Salvador, F., Oliva, M., 2016. Timing and new geomorphologic evidence of the last deglaciation stages in Sierra Nevada (southern Spain). Quat. Sci. Rev. 150, 110-129.

Palma, P., Oliva, M., Garcia-Hernandez, C., Gomez Ortiz, A., Ruiz-Fernandez, J., Salvador-Franch, F., Catarineu, M., 2017. Spatial characterization of glacial and periglacial landforms in the highlands of Sierra Nevada (Spain). Sci. Total Environ. 584-585, 1256-1267.

Pérez-Asensio, J.N., Frigola, J., Pena, L.D., Sierro, F.J., Reguera, M.I., RodríguezTovar, F.J., Dorador, J., Asioli, A., Kuhlmann, J., Huhn, K., Cacho, I., 2020. Changes in western Mediterranean thermohaline circulation in association with a deglacial Organic Rich Layer formation in the Alboran Sea. Quat. Sci. Rev. 228, 106075.

Rach, O., Brauer, A., Wilkes, H., Sachse, D., 2014. Delayed hydrological response to Greenland cooling at the onset of the Younger Dryas in western Europe. Nat. Geosci. 7, 109-112.

Rach, O., Kahmen, A., Brauer, A., Sachse, D., 2017. A dual-biomarker approach for quantification of changes in relative humidity from sedimentary lipid D/H ratios. Clim. Past 13, 741-757.

Rach, O., Hadeen, X., Sachse, D., 2020. An automated solid phase extraction procedure for lipid biomarker purification and stable isotope analysis. Org. Geochem. 142, 103995.

Raicich, F., Pinardi, N., Navarra, A., 2003. Teleconnections between Indian monsoon and Sahel rainfall and the Mediterranean. Int. J. Climatol. 23, 173-186.

Ramos-Román, M.J., Jiménez-Moreno, G., Camuera, J., García-Alix, A., Anderson, R.S., Jiménez-Espejo, F.J., Carrión, J.S., 2018a. Holocene climate aridification trend and human impact interrupted by millennial- and centennial-scale climate fluctuations from a new sedimentary record from Padul (Sierra Nevada, southern Iberian Peninsula). Clim. Past 14, 117-137.

Rasmussen, S.O., Bigler, M., Blockley, S.P., Blunier, T., Buchardt, S.L., Clausen, H.B., Cvijanovic, I., Dahl-Jensen, D., Johnsen, S.J., Fischer, H., Gkinis, V., Guillevic, M., Hoek, W.Z., Lowe, J.J., Pedro, J.B., Popp, T., Seierstad, I.K., Steffensen, J.P., Svensson, A.M., Vallelonga, P., Vinther, B.M., Walker, M.J.C., Wheatley, J.J., Winstrup, M., 2014. A stratigraphic framework for abrupt climatic changes during the Last Glacial period based on three synchronized Greenland ice-core records: refining and extending the INTIMATE event stratigraphy. Quaternary Science Reviews 106, 14-28 https://doi.org/https://doi.org/10.1016/j. quascirev.2014.09.007.

Ramos-Román, M.J., Jiménez-Moreno, G., Camuera, J., García-Alix, A., Scott Anderson, R., Jiménez-Espejo, F.J., Sachse, D., Toney, J.L., Carrión, J.S., Webster, C. Yanes, Y., 2018b. Millennial-scale cyclical environment and climate variability during the Holocene in the western Mediterranean region deduced from a new multi- proxy analysis from the Padul record (Sierra Nevada, Spain). Glob. Planet. Chang. 168, 35-53.

Raya Garrido, J., 2003. Composición isotópica del vapor de agua atmosférico en el sureste de la Península Ibérica. Editorial de la Universidad de Granada, Granada.

Renssen, H., Goosse, H., Roche, D.M., Seppä, H., 2018. The global hydroclimate response during the Younger Dryas event. Quat. Sci. Rev. 193, 84-97.

Rindsberger, M., Magaritz, M., Carmi, I., Gilad, D., 1983. The relation between air mass trajectories and the water isotope composition of rain in the Mediterranean Sea area. Geophys. Res. Lett. 10, 43-46.

Roberts, N., Jones, M.D., Benkaddour, A., Eastwood, W.J., Filippi, M.L., Frogley, M.R., Lamb, H.F., Leng, M.J., Reed, J.M., Stein, M., Stevens, L., Valero-Garcés, B., Zanchetta, G., 2008. Stable isotope records of late Quaternary climate and hydrology from Mediterranean lakes: the ISOMED synthesis. Quat. Sci. Rev. 27, 2426-2441.

Rodrigo-Gámiz, M., Martínez-Ruiz, F., Rodríguez-Tovar, F.J., Jiménez-Espejo, F.J., Pardo-Igúzquiza, E., 2014. Millennial- to centennial-scale climate periodicities and forcing mechanisms in the westernmost Mediterranean for the past 20,000 yr. Quat. Res. 81, 78-93.

Rozanski, K., Araguás-Araguás, L., Gonfiantini, R., 1993. Isotopic patterns in modern global precipitation. In: Swart, P.K., Lohmann, K.C., Mckenzie, J., Savin, S. (Eds.), Climate Change in Continental Isotopic Records. American Geophysical Union, pp. 1-36.

Sachse, D., Radke, J., Gleixner, G., 2004. Hydrogen isotope ratios of recent lacustrine sedimentary n-alkanes record modern climate variability. Geochim. Cosmochim. Acta 68, 4877-4889.

Sachse, D., Billault, I., Bowen, G.J., Chikaraishi, Y., Dawson, T.E., Feakins, S.J., Freeman, K.H., Magill, C.R., McInerney, F.A., Meer, M.T.J.V.D., Polissar, P., Robins, R.J., Sachs, J.P., Schmidt, H.-L., Sessions, A.L., White, J.W.C., West, J.B., Kahmen, A., 2012. Molecular Paleohydrology: Interpreting the Hydrogen-Isotopic Composition of Lipid Biomarkers from Photosynthesizing Organisms. Annu. Rev. Earth Planet. Sci. 40, 221-249.

Salgueiro, E., Naughton, F., Voelker, A.H.L., de Abreu, L., Alberto, A., Rossignol, L., Duprat, J., Magalhães, V.H., Vaqueiro, S., Turon, J.-L., Abrantes, F., 2014. Past circulation along the western Iberian margin: a time slice vision from the last Glacial to the Holocene. Quat. Sci. Rev. 106, 316-329.

Schirrmacher, J., Andersen, N., Schneider, R.R., Weinelt, M., 2020. Fossil leaf wax hydrogen isotopes reveal variability of Atlantic and Mediterranean climate forcing on the Southeast Iberian Peninsula between 6000 to 3000 cal. BP. PLoS One 15, e0243662.

Shanahan, T.M., McKay, N.P., Hughen, K.A., Overpeck, J.T., Otto-Bliesner, B., Heil, C.W., King, J., Scholz, C.A., Peck, J., 2015. The time-transgressive termination of the African Humid Period. Nat. Geosci. 8, 140.

Sierro, F.J., Hodell, D.A., Curtis, J.H., Flores, J.A., Reguera, I., Colmenero-Hidalgo, E., Bárcena, M.A., Grimalt, J.O., Cacho, I., Frigola, J., Canals, M., 2005. Impact of iceberg melting on Mediterranean thermohaline circulation during Heinrich events. Paleoceanography 20, PA2019.

Sierro, F.J., Hodell, D.A., Andersen, N., Azibeiro, L.A., Jimenez-Espejo, F.J., Bahr, A., Flores, J.A., Ausin, B., Rogerson, M., Lozano-Luz, R., Lebreiro, S., HernandezMolina, F.J., 2020. Mediterranean Overflow over the last 250 ky. Freshwater forcing from the tropics to the ice sheets. Paleoceanogr. Paleoclimatol. 35, e2020PA003931.

Smith, A.C., Wynn, P.M., Barker, P.A., Leng, M.J., Noble, S.R., Tych, W., 2016. North Atlantic forcing of moisture delivery to Europe throughout the Holocene. Sci. Rep. 6, 24745.

Spanish National Weather Agency - AEMet Open Data, 2020. AEMet Open Data. http:// www.aemet.es/es/datos abiertos/AEMET OpenData.

Sprenger, C., 2006. Groundwater Study for the Regional Granada Aquifer System (Southern Spain) Hydrochemistry and Isotope Study, Berlin.

Tierney, J.E., Zhu, J., King, J., Malevich, S.B., Hakim, G.J., Poulsen, C.J., 2020. Glacial cooling and climate sensitivity revisited. Nature 584, 569-573.

Toney, J.L., García-Alix, A., Jiménez-Moreno, G., Anderson, R.S., Moossen, H., Seki, O., 2020. New insights into Holocene hydrology and temperature from lipid biomarkers in western Mediterranean alpine wetlands. Quaternary Science Reviews 240, 106395 https://doi.org/10.1016/j.quascirev.2020.106395.

Torres, T., Ortiz, J.E., Soler, V., Delgado, A., Araujo, R., Valle, M., Rivas, M.R., Julià, R., Sánchez-Palencia, Y., Vega-Panizo, R., 2020. An analogue of dominance of tectonic over climatic forcing in intermontane coal-bearing basins: Padul (SE Spain). Int. J. Coal Geol. 227, 103530.

Toucanne, S., Zaragosi, S., Bourillet, J.F., Cremer, M., Eynaud, F., Van Vliet-Lanoë, B., Penaud, A., Fontanier, C., Turon, J.L., Cortijo, E., Gibbard, P.L., 2009. Timing of massive 'Fleuve Manche' discharges over the last 350kyr: insights into the European ice-sheet oscillations and the European drainage network from MIS 10 to 2. Quat. Sci. Rev. 28, 1238-1256.

Toucanne, S., Jouet, G., Ducassou, E., Bassetti, M.-A., Dennielou, B., Angue Minto'o, C. M., Lahmi, M., Touyet, N., Charlier, K., Lericolais, G., Mulder, T., 2012. A 130,000year record of Levantine Intermediate Water flow variability in the Corsica Trough, western Mediterranean Sea. Quat. Sci. Rev. 33, 55-73.

Trigo, R., Xoplaki, E., Zorita, E., Luterbacher, J., Krichak, S.O., Alpert, P., Jacobeit, J., Sáenz, J., Fernández, J., González-Rouco, F., Garcia-Herrera, R., Rodo, X. Brunetti, M., Nanni, T., Maugeri, M., Türke, M., Gimeno, L., Ribera, P., Brunet, M., Trigo, I.F., Crepon, M., Mariotti, A., 2006. Chapter 3 Relations between variability in the Mediterranean region and mid-latitude variability. In: Lionello, P., MalanotteRizzoli, P., Boscolo, R. (Eds.), Developments in Earth and Environmental Sciences. Elsevier, pp. 179-226.

Valle, F., 2003. Mapa de Series de Vegetación de Andalucía. Editorial Rueda, S.I., Madrid. 
Voelker, A.H.L., de Abreu, L., Schönfeld, J., Erlenkeuser, H., Abrantes, F., 2009. Hydrographic conditions along the western Iberian margin during marine isotope stage 2. Geochem. Geophys. Geosyst. 10, Q12U08.

Volosciuk, C., Maraun, D., Semenov, V.A., Tilinina, N., Gulev, S.K., Latif, M., 2016. Rising Mediterranean Sea Surface Temperatures Amplify Extreme Summer Precipitation in Central Europe. Sci. Rep. 6, 32450.

Wagner, B., Vogel, H., Francke, A., Friedrich, T., Donders, T., Lacey, J.H., Leng, M.J., Regattieri, E., Sadori, L., Wilke, T., Zanchetta, G., Albrecht, C., Bertini, A.,

Combourieu-Nebout, N., Cvetkoska, A., Giaccio, B., Grazhdani, A., Hauffe, T., Holtvoeth, J., Joannin, S., Jovanovska, E., Just, J., Kouli, K., Kousis, I., Koutsodendris, A., Krastel, S., Lagos, M., Leicher, N., Levkov, Z., Lindhorst, K., Masi, A., Melles, M., Mercuri, A.M., Nomade, S., Nowaczyk, N., Panagiotopoulos, K., Peyron, O., Reed, J.M., Sagnotti, L., Sinopoli, G., Stelbrink, B., Sulpizio, R.,
Timmermann, A., Tofilovska, S., Torri, P., Wagner-Cremer, F., Wonik, T., Zhang, X., 2019. Mediterranean winter rainfall in phase with African monsoons during the past 1.36 million years. Nature 573, 256-260.

Zanchetta, G., Bar-Matthews, M., Drysdale, R.N., Lionello, P., Ayalon, A., Hellstrom, J.C., Isola, I., Regattieri, E., 2014. Coeval dry events in the central and eastern

Mediterranean basin at 5.2 and 5.6ka recorded in Corchia (Italy) and Soreq caves (Israel) speleothems. Glob. Planet. Chang. 122, 130-139.

Zielhofer, C., Fletcher, W.J., Mischke, S., De Batist, M., Campbell, J.F.E., Joannin, S.,

Tjallingii, R., El Hamouti, N., Junginger, A., Stele, A., Bussmann, J., Schneider, B., Lauer, T., Spitzer, K., Strupler, M., Brachert, T., Mikdad, A., 2017. Atlantic forcing of Western Mediterranean winter rain minima during the last 12,000 years. Quat. Sci. Rev. 157, 29-51. 